Portland State University

PDXScholar

$5-8-2002$

\title{
Discrimination and Nepotism within Police Specialty Units
}

Robert Norvell Hollins III Portland State

Follow this and additional works at: https://pdxscholar.library.pdx.edu/open_access_etds

Part of the Criminology and Criminal Justice Commons Let us know how access to this document benefits you.

\section{Recommended Citation}

Hollins, Robert Norvell III, "Discrimination and Nepotism within Police Specialty Units" (2002). Dissertations and Theses. Paper 3094.

https://doi.org/10.15760/etd.3096

This Thesis is brought to you for free and open access. It has been accepted for inclusion in Dissertations and Theses by an authorized administrator of PDXScholar. Please contact us if we can make this document more accessible: pdxscholar@pdx.edu. 
The abstract and thesis of Robert Norvell Hollins III for the Master of

Science in Administration of Justice were presented May 8, 2002, and accepted by the thesis committee and the department .

COMMITTEE APPROVALS:

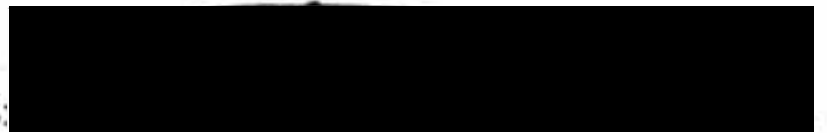

Gary R. Perlstein, Chair //

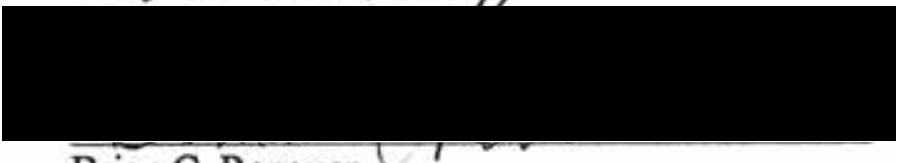

Brian C. Renauer

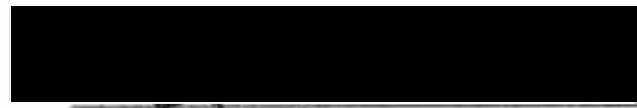

Grant M. Farr

Representative of the Office of Graduate Studies

PROGRAM APPROVAL:

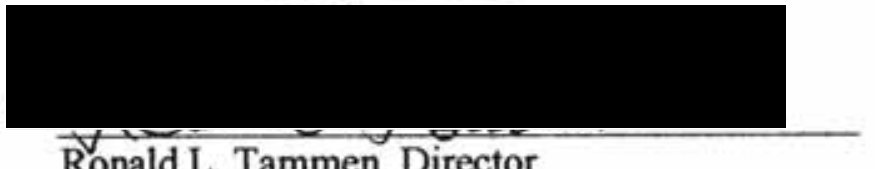

Ronald L. Tammen, Director

Mark O. Hatfield School Of Goverment 


\begin{abstract}
An abstract of the thesis of Robert Norvell Hollins III for the Master of Science in Administration of Justice presented May 8, 2002.
\end{abstract}

Title: Discrimination and Nepotism within Police Specialty Units.

A career as a police officer has served as a legitimate avenue for many Black Americans to elevate themselves from numerous low paying less prestigious jobs, to a more respectable better paying secured occupation that has a higher social economic status. The general perception related to the civil service position of a police officer, suggests that it is an occupation which should offer an environment free from discrimination and nepotism, thereby allowing fair treatment and equal access for advancement to all individuals employed within the police organization.

The concept of a police organization that offers fair treatment and equal access for advancement to all of its employees in a climate that is free from discrimination and nepotism is the subject of considerable skepticism among many black police officers.

Police departments throughout the United States of America have been challenged by a highly visible accusation of discrimination and nepotism in regards to the selection process and the police personnel selected to become members of elite police specialty units. 
This thesis traces the historical involvement of black police officers in The United States and their progression to obtain equality and fair treatment as police officers within the law enforcement community.

This thesis examines the racial demographics of eighteen (18) police departments located in various sections of the United States and the racial demographics of the elite police specialty units which are incorporated within each police department.

In addition, this thesis will analyze collected data from the police departments that participated in the study and determine if the minority representation within each of the police department's elite police specialty units is equal to the general population which the police departments serve and proportionate to the minority representation within the police department.

Finally, this thesis will examine data identifying Black American's representation in significant areas of the criminal justice system, thus analyzing the correlation between Black American's over-representation in the criminal components of the criminal justice system and their under-representation within police departments and elite police specialty units. 


\title{
DISCRIMINATION AND NEPOTISM \\ WITHIN POLICE SPECIALTY UNITS
}

by

ROBERT NORVELL HOLLINS III

A thesis submitted in partial fulfillment of the requirements for the degree of

\author{
MASTER OF SCIENCE \\ in \\ ADMINISTRATION OF JUSTICE
}

Portland State University

2002 


\section{TABLE OF CONTENTS}

List of Tables $\quad$ iii

List of Figures iv

CHAPTER 1: Introduction 1

$\begin{array}{lr}\text { Background } & 1\end{array}$

$\begin{array}{lr}\text { Problem Statement } & 6\end{array}$

$\begin{array}{ll}\text { Research Questions } & 11\end{array}$

$\begin{array}{lr}\text { Definition of terms and concepts } & 13\end{array}$

$\begin{array}{lr}\text { Literature Review } & 14\end{array}$

$\begin{array}{ll}\text { Research Design } & 17\end{array}$

$\begin{array}{lr}\text { CHAPTER 2: Law and Order } & 19\end{array}$

Law Enforcement: Struggle For Black Police Officers 20

CHAPTER 3: The Task of Becoming A Member of An Elite 23

Police Specialty Unit

$\begin{array}{ll}\text { Good Ole Boy Network } & 24\end{array}$

Police Departments That Participated 26

In The Study.

Black Police Officer's Representation $\quad 27$

White Police Officer's Representation $\quad 28$

Hispanic Police's Representation $\quad 29$

CHAPTER 4: Racial Representation In Police $\quad 50$

Departments 
CHAPTER 5: The Chief of Police Factor 58

White Chiefs of Police $\quad 58$

Black Chiefs of Police $\quad 59$

Hispanic Chiefs of Police 61

CHAPTER 6: Discrimination Lawsuits $\quad 64$

$\begin{array}{lr}\text { Black Police Personalities. } & 69\end{array}$

$\begin{array}{ll}\text { T-Test Results and Conclusions } & 73\end{array}$

$\begin{array}{ll}\text { Summery and Conclusion } & 77\end{array}$

$\begin{array}{ll}\text { Bibliography } & 79\end{array}$ 


\section{LIST OF TABLES.}

TABLE 1: Index of Black Representation in Police Departments. 32

TABLE 2: Index of Black Representation in Police Specialty Units. 33

TABLE 3: Index of Black Representation in Police Specialty Units 34

Calcultated With The Local Population.

TABLE 4: Index of White representation in Police Departments. 37

TABLE 5: Index of White Representation in Police Specialty Units. $\quad 40$

TABLE 6: Index of White Representation in Police Specialty Units 42

Calculated With The Local Population.

TABLE 7: Index of Hispanic Representation in Police Departments. $\quad 44$

TABLE 8: Index of Hispanic Representation in Police Specialty Units. $\quad 46$

TABLE 9: Index of Hispanic Representation in Police Specialty Units $\quad 48$

Calculated With The Local Population.

TABLE 10: Police Officers/Police Chiefs by Race For Police Departments. 62

TABLE 11: Police Officers/Police Chiefs by Race For Specialty Units. $\quad 62$

TABLE 12: Blacks Sample Statistics.

TABLE 13: Whites Sample Statisics. $\quad 74$

$\begin{array}{ll}\text { TABLE 14: Hispanics Sample Statisics. } & 74\end{array}$

TABLE 15: Independent Samples Test. 75

TABLE 16: Coefficients Test.

TABLE 17: Coefficients Test. 


\section{LIST OF FIGURES}

FIGURE 1: Map of The United States Illustrating The Cities/Police

Departments That Participated In This Study.

FIGURE 2: Index of Black Representation in Police Departments.

FIGURE 3: Index of Black Representation in Specialty Units/Departments. 36

FIGURE 4: Index of Black Representation in Specialty Units/Population. $\quad 37$

FIGURE 5: Index of White Representation in Police Departments. 39

FIGURE 6: Index of White Representation in Specialty Units/Departments. 41

FIGURE 7: Index of White Representation in Specialty Units/Population. 43

FIGURE 8: Index of Hispanic Representation in Police Departments. $\quad 45$

FIGURE 9: Index of Hispanic Representation in Police Specialty 47

Units/Departments.

FIGURE 10: Index of Hispanic Representation in Police Specialty. $\quad 49$

Units/Population.

FIGURE 11: Police Department's Disproportionate/Population

Representation Chart.

FIGURE 12: Police Specialty Unit's Disproportionate/Population

Representation chart.

FIGURE 13: Police Specialty Unit's Disproportionate/Department

Representation chart. 
FIGURE 14: Police Index of Race Representation: Department/Population. $\quad 55$

FIGURE 15: Police Index of Race Representation, Specialty Unit/Department. 56

FIGURE 16: Police Index of Race Representation, Specialty Unit/Population. 57 


\section{CHAPTER 1}

Introduction

\section{BACKGROUND}

For decades, the majority of black police officers have been at the bottom level of the law enforcement hierarchy. In the United States of America, there are approximately 600,000 police officers of which approximately $50,000(8.3 \%)$ are black police officers. (Emerge.1995.p.29)

For many years, positions within the police community have been primarily dominated by white males who have chosen law enforcement as a career. Within the past 20 years, the faces of law enforcement have changed as a result of the increased numbers of minorities and women entering law enforcement .

For one to understand the plight of the black police officer's struggle to obtain equality within the police community, one must examine the history of law enforcement in America, as it relates to Black Americans. In the minds of many, it is the common belief that Black Americans have always been policed in one way or another. Be it by some form of official law enforcement, or by an unofficial militia assigned the task of regulating and monitoring their actions. The policing of Black Americans began in the seventeenth century, when Africans were forcefully removed from their home land in Africa, during the Atlantic Slave Trade, and brought to the United States of America and exploited as slaves.

At the time of the first census in the United States in 1790 , there were 757,181 
Africans in the country, constituting 19.3 percent of the total population. All but 59,577 were slaves. Africans enslaved in America were a troublesome presence. Belying their captor's claim that they were made for slavery, Africans rebelled against the institution in a variety of ways. They resisted on a daily basis by refusing to work, destroying crops and farm implements, and killing livestock. They poisoned their owners, destroyed property through arson, and fought with their owners and other whites. Some ran away from slavery; others cooperated with Native Americans or white indentured servants to resist through physical force. This resort to violence created the greatest problem for the whites in the colonial period of American history. They lived in constant fear of slave rebellions, and as a result passed many laws to deter, control, and suppress such insurrections. (Black Police In America 1996. pp. 1-2).

Along with these new laws came the slave patrols. The slave patrols were the first distinctively American policing system, and it set the pattern of policing that Americans of African descent would experience throughout their history. The slave patrollers consisted of all white males who were authorized to stop, search, whip, maim, and even kill any African slave caught off the plantation without a pass, engaged in illegal activities, or running away. The colonial slave patrols exercised awesome powers which were oftentimes abused. (Black Police In America 1996. pp. 1-2)

During the first three centuries of their presence in North America, few Black Americans had the opportunity to serve in the police or constabulary forces 
organized in North America. Few Black Americans had the opportunity to serve in the police or constabulary forces organized by Americans to preserve the peace and maintain order. Moreover, during the colonial and antebellum periods of American history, when most Black Americans were slaves and were considered to be a threat to the public order, some of the earliest police systems were organized to patrol their activity and regulate their behavior. According to several scholars, Black Americans have been patrolled and policed throughout their history in the Americas and have had to endure both legal and extralegal police methods as a consequence. Given this legacy, it was rare for Black Americans "the policed" to become members of the patrols and forces organized to suppress them. (Black Police In America. 1996. p. XIII)

In recent years, everywhere that Black Americans serve as chiefs, ranking officers, or ordinary patrolmen, that service has been hard fought and hard won. Indeed, the experience of Black Americans in law enforcement parallels the history of black participation in almost every other form in governmental service in North America. Black Americans were grudgingly accepted as police officers. Even after they where hired, they were still denied equal authority with white police officers, discriminated against in promotion and assignment, segregated, expelled, banned, and even prevented from wearing their uniforms. In some cities they were denied

the right to carry arms and arrest White Americans. (Black Police In America 1996.p. 1.) 
Entry into law enforcement has long been a means by which impoverished immigrant groups have attained economic and political power. But, in their efforts to pursue this same avenue of socioeconomic advancement, Black Americans have had to overcome obstacles that no immigrant group has encountered. Black Americans had to acquire political power first before they could achieve meaningful participation in law enforcement.(Black Police In America. 1996. p. 1.)

It was in a racist and hostile atmosphere in the nineteenth century, that first Black Americans became law enforcement officers. They served in a racist, slave society and implicitly accepted the oppression of Black Americans in order to carry out their duties By accepting the racial status quo and the legal oppression of other Black Americans, these law enforcement officers became the first black police officers to confront the paradox of policing a society where the color of a person's skin often determined guilt or innocence. They also became the first to accept such roles because they believed that they could improve their own precarious position in a society where status was based on skin color. (Black Police In America. 1996.p.7)

It was during the 1960 s when the employment of Black Americans as police officers was of great interest, because of the Kernel Commission's recommendation that American law enforcement agencies increase their number black police officers to counter the charge that predominantly white police forces constituted occupying armies established to police and oppress (not protect) Black American 
communities. The resulting recruitment and the promotion of black law enforcement officers in the late $1960 \mathrm{~s}$ and the late 1970 s forced police agencies to attempt to reform long-standing policies that denied Black Americans full access to police jobs, and virtually regulated them to second-class status police officers. Needless to say, the attempt to reform the historically racial policies in American police departments only engendered more problems, especially when reform meant challenging the hegemony of white police officers for positions and promotions in policing. (Black Police In America. 1996. p. xvii)

It is also due to the civil rights movement of the 1960 s, affirmative action, law suits, education, more awareness, and a changing society, that many of the external barriers that at one time excluded Black Americans from entering law enforcement have been knocked down. While the external barriers are continuously falling, it is the internal barriers that are on the up rise and are becoming increasingly more difficult for black police officers to overcome and move from the rank and file position of patrol officer to the elite specialty units and higher ranking supervisory management positions within police departments.

It is the internal barriers that black police officers must overcome in order to become members of the elite police specialty units within police departments. These elite police specialty units are as follows: special weapons and tactics (S.W.A.T), bomb squad, narcotics, vice, k-9 unit, motorcycle unit, horse patrol, river boat unit, search and rescue, diving division, air support, gang unit, auto theft unit, street crimes unit, and liquor control to name a few. 
The aforementioned police specialty units, for the most part, are lateral positions within police departments which are arbitrarily staffed with carefully selected police officers from the rank and file position of patrol officer. The selection process normally consists of a background check, an internal interview by the applying officer's supervisors and peers who are currently assigned to the specific police specialty unit that the applicant police officer is applying for. There is also a regiment of specific assessment tasks that are related to the position being applied for , that the applicant police officer must demonstrate. Lastly, for some positions the applicant police officer may be required to take a written examination, which in nearly all cases is reviewed and scored internally by a supervisor within the police specialty unit. Rarely does an outsider or a person not associated with the police specialty unit participate in the selection process of new members into the specialty unit.

\section{PROBLEM STATEMENT:}

The problem that this thesis addresses is the under-representation of black police officers within police department's elite police specialty units. When compared to the general United States population, it appears that Black Americans are overrepresented in criminal components of the criminal justice system. The 1990 United States Census reported that blacks represent $12.1 \%$ of the United States population. 
(Bureau of the Census 1991). There are approximately 600,000 active police officers employed in nearly 20,000 separate police organizations in The United States, of which approximately $20,000(8.3 \%)$ are black police officers (Emerge 1995 p. 29).

Of all the arrests made in 1997, (ages 18 and older), $30.4 \%$ of the offenders were black (Sourcebook 1998). In 1997 black offenders were responsible for committing $41.1 \%$ of the violent crimes in The United States (Sourcebook 1998). The data collected estimates that in $1996,9 \%$ of the adult black male population in The United States was under correctional supervision. (Sourcebook 1998). Finally, the data indicates that blacks represent $42.2 \%$ of the prisoners under the sentence of death in The United States. (Sourcebook 1998).

The majority of police officers in the United States are white, representing an overwhelming 87\%. (Emerge 1995.p 29). The United States Census reported that $83 \%$ of the United States population was white (Bureau of Census 1991). The over-representation is nothing new or unheard of, to the contrary, White dominance in law enforcement has been a way of life in the modern police force ever since its creation in the early 19 th century. This phenomenon causes one to wonder why it exists and why it is so prevalent throughout the United States and within the various police agencies. It is the intent of this thesis to examine data and evaluate if discrimination and nepotism are relevant factors in the under-representation of black police officers in police specialty units and police departments that 
participated in this study.

White racial dominance of blacks in America from the establishment of black slavery in the seventeenth century, to the establishment and consolidation of black ghettos in the late nineteenth and throughout the twentieth centuries depended upon systems of white policing. Without such systems, whites would have had a difficult time developing and maintaining their ideology of racial superiority. (Cashmore 1991: 66).

As history suggests, slavery necessitated the first system of white policing of the black populations. As the Anglo-Saxon Americans formed their various slave institutions in the early development of the United States, they had to design various safe-guards to protect the white majority from black rebellions. This was done by creating slave codes and black codes that regulated the behavior of black slaves in the dominant white society. Furthermore, in order for these codes to be effective, they had to be strictly and severely enforced by the ruling class. In 1686 a colonial act that was instituted gave any member of the white ruling class the right to apprehend, chastise, and order home any slave that was off his master's plantation without a pass. It was every member of the white majority's duty to take an active participatory role in the policing of the black slave. Furthermore, if they failed to uphold their duties, they were fined and punished. One must realize that this policing strategy had a devastating effect on race relations in the South. Even with the abolishment of slavery in 1862 effective January 1,1863 , the fear of black rebellion remained prevalent and the desire to police the black 
population never completely died. The ruling class that being Anglo-Saxon Americans, wanted to still obtain the ability to have white dominance and white superiority over all segments of the black population.

The white policing rule had a spill over effect on the generations to follow in law enforcement. The racist, discriminatory beliefs and views of colonial America were transcended and taught throughout history. Although somewhat diluted, there is evidence that these destructive beliefs still remain in present day times. For example, in 1997 , blacks were the victims of $64.9 \%$ of the bias motivated hate crimes that were reported in The United States. Furthermore, in 1997, anti-black hate crimes represented $66.2 \%$ of the race related hate crimes that were in The United States. (Sourcebook 1998).

Racism and discrimination in law enforcement agencies were wide spread and rampant throughout the early to middle decades of the twentieth century. Black Americans were virtually nonexistent in law enforcement agencies. In cities where the Black American population was the majority, the percentage of black police officers was inconsistent with and disproportionate to the number of blacks in the general population.

For example, an unnamed police agency relatively small in size, and having state wide authority located in the Southeastern section of the United States, was known for the exclusion of Black-Americans and brutality toward Black-Americans based on the disproportionate number of arrests and use of force. It was also determined that this police agency had not hired a Black-American since its 
inception as a law enforcement institution, or hired a female police officer in 42 years.

To institute an element of balance for the under-representation of black police officers in police departments, and the unfair treatment of blacks and members of other minority groups, hiring practices, policies, and affirmative action quotas were forcefully incorporated by the political powers and court system in order to force police departments to hire Black Americans and other minorities. As one could imagine, the police officers who joined the ranks during this type of social change were not wholeheartedly welcomed. Because of the reluctance of the police agencies willingness to accept the quota system, and claim that it was unfair to white police officers, the quota system was eventually dissolved by a United States Supreme Court ruling, and replaced with various forms of affirmative action programs and functions.

One must realize that police officers are just as human as the next person, and have the same likes, dislikes and problems as any other person. Therefore, it's not a stretch of the imagination to believe that they too share some of the same racist, discriminatory ideologies as some members do in the general public, which stem from the slave trade era of colonial America. That is to maintain superiority and rule over the Black-American population, the innate, historical concept instilled by racist white forefathers.

As a result of a rapidly changing society, combined with raising crime rates, the 
increase of professional and specialized criminals, and the need to reassure the public's confidence and trust in police department's fight against crime, aggressive proactive law enforcement specialization has become the hallmark of progressive police departments. Police departments are limiting the responsibilities and reducing work load of the traditional "patrol officer", who is more involved and working closer with the community, to a non-traditional system of policing, in which highly trained police officers are carefully selected and assigned to elite police specialty units specifically designed to address certain crimes and areas of law enforcement.

Although this may be welcomed news for many white police officers, it is somewhat disheartening and viewed by many black police officers as method to restrict their advancement within the organization, yet another internal barrier to overcome, and a subversive tactic to limit and or exclude black police officer's participation and involvement as members of elite police specialty units.

\section{RESEARCH QUESTIONS:}

The overwhelming perception that discrimination and nepotism exists in modern police departments, and are considered as internal barriers that black police officers must overcome in order to become members of elite police specialty units, weakens morale and causes a destructive friction to develop between police officers 
of different races. This thesis attempts to clarify the accuracy of this perception utilizing the racial demographics of eighteen police departments and their elite police specialty units combined with and the racial demographics of the cities where the police departments are located. The data collected and used in this thesis is guided by a specific set of research questions:

1. Does discrimination and nepotism exist in modern day police departments and act as internal barriers limiting black police officer's advancement into elite police specialty units.

2. Does the racial demographics of the population where the police departments are located, affect the racial demographics of the police officers assigned to elite police specialty units.

3. Does the racial demographics of police department's personnel affect the racial demographics of the police officers assigned to elite police specialty units.

4. Is there an interaction between the race of the Chief of Police and the race of the police officers assigned to elite police specialty units.

5. Does the historical ideologies of policing and colonial American beliefs affect black police officers ability to become members of elite police specialty units. 6. How do black police officers overcome the internal barriers of discrimination and nepotism, and establish representation within elite police specialty units that is proportionate with the percentage of blacks in the general population and the particular police department in which the police specialty unit is based. 


\section{DEFINITION OF TERMS AND CONCEPTS:}

POLICE DEPARTMENT: A force organized by city, state, or government to maintain order, prevent and detect crime, and enforce laws and protect life.. POLICE SPECIALTY UNIT: A group of highly trained carefully selected elite police officers assigned to a particular subdivision of a police department and given the task and responsibility of specializing in a specific area of law enforcement. INTERNAL BARRIER: A Bureaucratized non-structural obstacle within the police organization which is utilized by individuals in positions of power and having decision making authority to limit the advancement and exclude police officers from becoming members of elite police specialty units.

BLACK POLICE OFFICER: A person of African-American descent that is a member of a police force.

NEPOTISM: Favoritism shown in business or employment on the basis of family or friend relationship.

DISCRIMINATION: To make a distinction in favor of or against a person based on prejudice.

PREJUDICE: An unfavorable opinion or decision formed beforehand or without knowledge based on hatred or dislike directed against a racial, religious, or national group.

RACE: The race of the population or police officer is categorized as follows: white, black, and Hispanic/Latino. 
RACIAL DEMOGRAPHIC: The statistics of race related to the population and/or an organization of people.

OVER-REPRESENTATION: A specific number or percentage of people identified as belonging to a particular race represented within a sub-section, that is disproportionate to and exceeds the percentage of people of the same race within the main section or body of people being compared to.

\section{LITERATURE REVIEW:}

There have been several studies performed, and considerable research conducted in the area of blacks in law enforcement. Much of the research has concluded that the occupation of a police officer hasbeen primarily been dominated by white males. The research and data indicate that black police officers are overcoming many of the barriers that, for so many decades, have kept them excluded from law enforcement as a career choice, and viewed as second-class citizens. The most recent research implies that unequal treatment and discrimination still exist within the law enforcement community across the nation.

For the most part, the data and research suggest that opportunities within law enforcement are continually becoming available for black police officers. In the areas of recruitment and new hires for blacks, and other minority groups, the data indicates that the numbers are increasing. As indicated by the U.S. Department of Justice: Bureau of Justice Statistics 2002, “ from 1987-1997, within local police 
departments, minority representation has increased from $14.5 \%$ to $21.5 \%$. I would concur with the prior statement. However, such is not the case when it comes to black police officers and their representation within elite police specialty units.

Elite police specialty units are relatively new to the law enforcement crime fighting arsenal. There has been very little published research or documentation specifically addressing elite police specialty units or the personnel assigned to them. Despite the lack of available data, I compiled articles, texts, and statistical data to assist with this study, and provide insight into elite police specialty units.

The text "Black in Blue" by Nicholas Alex, addresses the frustrations, lack of achievements, and the feeling of inequality felt by 41 black police officers of the New York City Police Department during the 1960's. The general consensus from the black police officer's point of view, is that they are a small minority and encounter discrimination on a daily basis within the police department. The author suggests that the black police officers are engaged in a constant struggle to prove themselves. Many of the black police officers expressed concern that they were treated as less than equal by their peers and supervisors, and were often passed over for promotions and police specialty assignments.

Although this study took place in the 1960 's, more recent data indicates that there is a sufficient amount of evidence to support the claim by both black and white police officers that discrimination existed and continues to exist in the 1990's and 2000's. Furthermore, recent data suggest that black police officers continue to have a minority representation within law enforcement, and encounter race related 
frustrations associated with being a police officer.

The text "Black Police In America" by W. Marvin Dulaney, traces the historical journey of the black police officer's role and involvement in law enforcement from virtually total exclusion to holding top managerial positions in some of the nation's largest metropolitan police departments.

The research conducted by Mr. Dulaney concurs with prior research, which indicates that blacks have come a long way since the antebellum era of American history. However, the research suggests that black police officers continue to find themselves as victims subjected to discrimination within law enforcement, and perpetrators of reverse discrimination, as they achieve success and advance to the higher level positions within the law enforcement community.

The article by Ben Johnson (1993), discusses the public's perception of blacks as criminals and less patriotic than non-blacks, as the result of media journalist's portrayal of blacks when reporting violent crimes. He contends that the public is constantly bombarded with mis-information regarding dangerous black criminals which clouds and alters their perception as it pertains to the entire black population. In Nick Charle's and Chrisena Colman's article "Badge Of Racism" (1995), they examine why so many black undercover police officers are accidentally shot, killed, and physically assaulted by white police officers who work in the same police department. Moreover, they contend that during their research, no white undercover police officer had been shot or killed by a black police officer. In the article, the writers concur with the research and conclusion made by Ben Johnson. 
The writers indicate that their research suggests that black males are perceived as criminals, and it is because of this perception that white police officers mistakenly shoot undercover black police officers in the line of duty. The title "Badge of Racism," implies that one race is superior and uses the badge to inflict hatred upon an inferior race. All of the research concluded that in modern day times, discrimination within the law enforcement community exists and appears to be spreading.

\section{RESEARCH DESIGN.}

For the purpose of this study, data collection began by establishing a database from data that was obtained through a questionnaire mailed to the office of the chief of police and the office of the municipal director of personnel for police departments in 50 of the largest cities in the United States. The response was as follows: 18 or ( $36 \%)$ of the police departments returned completed questionnaires, 11 or $(22 \%)$ of the police departments returned incomplete questionnaires, and 21 or $(42 \%)$ of the police departments did not reply.

The indexes of white, black, and Hispanic police officer's representation within the elite police specialty units of the police departments that returned completed questionnaires were calculated and compared to the percentage of whites, blacks, and Hispanics in the local population utilizing data from the 1990 
United States Census.

The race of the chiefs of police and important demographic data provided by the United States Census Bureau was analyzed to determine if there was a correlation with the percentage of white, black, and Hispanic police officers assigned to elite police specialty units within the responding police departments.

Secondary data such as newspaper articles, police statistical journals, crime index reports, police department public information data, and statistical data from components of the criminal justice system were analyzed for the purpose of developing a hypothesis to explain black police officer's under-representation within elite police specialty units.

A historical analysis of the black police officer's inception into law enforcement was employed in order to obtain a historical perspective and evaluate the black police officer's role and advancement in law enforcement. Finally, civil law suits by police officers alleging discrimination in the work place provided important informational data to support this thesis. 


\section{CHAPTER 2}

\section{LAW AND ORDER.}

Law and order implies the protection of life and property, but it bears overtones of racism on the part of a large number of White Americans who feel that, no matter how recently they acquired it, they have a stake in American society by virtue of years of prosperity, by of owning a home, an automobile, and having a relatively well-paying job that is protected by seniority and tenure. The advocates and supporters of law and order include many White Americans at all occupational and income levels, who see the mobility and new political aggressiveness of Black Americans as a threat to their racial dominance over their society. For the issue of law and order involves deep and historic conflicts in the meaning, emotions, and institutions that are at the very root of American society. (Black in Blue. 1969. pp. xi-xii)

In keeping the above philosophy in mind, one can identify the historical origin of the black police officer's dilemma and attempt to over-come the internal discriminatory bureaucratic barriers that they are confronted with, as they attempt to become members of elite police specialty units. 


\section{LAW ENFORCEMENT : STRUGGLE FOR BLACK POLICE OFFICERS}

Law enforcement is a relatively low-prestige occupation. It attracts personnel to whom the income, security, and prestige is, however, greater than they might otherwise achieve. Law enforcement has historically attracted white immigrants and their children, who used law enforcement as the first step in the process of achieving mobility in American society. As salaries have risen, and as these groups have moved into the upper levels of the law enforcement hierarchy, white police officers have begun to achieve a stake in American society. As immigrants, and now as the children of immigrants, white police officers view new groups coming to the fore in urban society as less "American" than themselves, as having little respect for the proprieties of middle-class life, for the law as they define it, and for the police officers themselves as White Americans and guardians of the law. (Black In Blue. 1969. pp.xvii-xviii).

The very conditions of discrimination, segregation and the lack of opportunity make law enforcement attractive to Black Americans. It is the lack of alternative opportunities combined with the possibility of gaining employment at a relatively secure and well-paying civil service job, that makes law enforcement an attractive career choice. (Black In Blue. 1969. p. xviii) .

Surrounding the occupational core of the black police officer's roles are a set of cross pressures, role contradictions, and marginalities that threaten their original justification for entering the force. The black police officer sees the police force as 
dominated by White Americans and officialdom who places every possible obstacle in the path of their advancement. The black police officer is assigned the worst beats , and given little chance to enter specialized services. The black police officer is most frequently assigned to ghetto communities where he or she is used to maintain law and order. All too often, the black police officer is thought to be an " uncle Tom " or "Mr. Charlie's boy," or perceived as an agent of the white community, used to oppress and repress his friends and neighbors. (Black In Blue. 1969. p. xix).

The black police officer, therefore, can never escape his racial identity while serving in his official role. In the black community, the black police officer can never be a simple human being, he is always thought of as a police officer. The black police officer attempts to escape his uniform as soon as possible after his tour of duty. He avoids the friends of his youth in order to avoid learning of criminal behavior. His friends avoid him for similar reasons or because they think of him as a traitor. He does not socialize with the white police officers in his afterduty hours, partly because he not the same race, and mostly because he is not fully accepted and trusted by his white police officer peers outside the job. In short, he is drawn into an enclave of black police officers, he becomes a member of a minority group within a minority group. Thus, he is doubly marginal. The black police officer does not receive the same recognition from other middle-class blacks because he has made it into the middle-class world. He has been placed in the 
position of having to work with and within the agencies of the white community. ( Black In Blue.1969. p. xx ).

The Black person who enters into the police role is subject to all of the tensions and conflicts that arise from police work. Moreover, the conflicts are compounded for the black police officer. He is more than a black person to his ethnic group because he represents the guardian of white society, yet he is not quite a police officer to his working companions because he is a member of an inferior racial category. ( Black In Blue 1969. p. 14 ). 


\section{CHAPTER 3}

\section{THE TASK OF BECOMING A MEMBER OF AN ELITE POLICE SPECIALTY UNIT}

The organizational structure of police departments does in fact allow discrimination to take place in the area of assigning police officers to police specialty units. There is a great deal of discretion that is built into the police structure which affords individuals in power the opportunity to allow internal barriers such as nepotism and discrimination to enter into the equation during the selection process, by which police officers are arbitrarily selected to become members of elite police specialty units.

The procedure for becoming a member of an elite police specialty unit can range from being a fair organized structured competitive selection process that affords all applicants an equal opportunity to become a member of a police specialty unit, to a process that is discriminatory, unfair, abundant with nepotism and favoritism with predetermined selections. It is the latter which allows individuals in power the opportunity to misuse and abuse their authority.

As the doors open to more Black Americans who select law enforcement as a career choice, the doors and opportunities that lead to positions within elite police specialty units are closing on them. Consequently, the number of black police officers represented in elite police specialty units is considerably lower than their representation in the community which they serve and the rank and file entry level 
patrol officer positions. Moreover, $50 \%$ of the police departments mentioned in this study had a higher representation of black police officers employed within the police agency, when compared to the percentage of black police officer's representation within police specialty units.

\section{GOOD OLE BOY NETWORK}

The "good ole boy network" is a phrase within the law enforcement community which refers to a group of police officers who share a close bond with each other. Based on the research, the "good ole boy network" can also be an internal police barrier that black police officers encounter when they attempt to become members of elite police specialty units. In this system, individuals belong to an internal network, and are bonded together by occupational relationships, friendships, family ties, social interactions, and various hobbies. Many police officers who are part of the "good ole boy " network are in managerial positions, and have the authority to arbitrarily select and assign police officers to elite police specialty units. Thereby providing rank and file police officers who are also part of the " good ole boy " network, the inside tract in the selection process and an unfair advantage in becoming members of elite police specialty units. The " good ole boy " network is dominated by white male police officers. Black police officers rarely are part of the network, due in part to the lack of social interaction between black and white police officers.

Another method of advancement and upward mobility into elite police specialty 
units is the "kinship tradition." Within this system, there exists a long history and tradition of law enforcement personnel in various families, which information obtained through years of experience and knowledge related to law enforcement and police work, is passed on to family members interested in pursuing a career in law enforcement and advancing into elite police specialty units.

Based on the data and research compiled during this study, (the good ole boy network) appeared to display and produce an environment conducive to an atmosphere which individuals within the network practiced and tolerated discrimination, favoritism, and nepotism on a routine basis. Moreover, the data suggests that it is the "good ole boy network" within the law enforcement community, which black police officers encounter a fair amount of hostility and resistance when trying to penetrate areas within the law enforcement arena where black representation is minimal and or non-existent.

The data suggests that in modern day times, the "good ole boy network" continues to manifest itself as a major barrier that black police officers must overcome in order to be successful and obtain advancement within law enforcement community. Furthermore, the data tends to suggest, as more minority police officers select law enforcement as a career, particularly within police departments and cities that have a relatively low representation of minorities, the the increased numbers of minority police officers will have a diluting effect on the membership and influence of the "good ole boy network". 
POLICE DEPARTMENTS THAT PARTICIPATED IN THE STUDY:

1. CHICAGO, IL

2. HOUSTON, TX

3. DETROIT, MI

4. DALLAS, TX

5. SAN ANTONIO, TX

6. EL PASO, TX

7. NEW ORLEANS, LA

8. DENVER, CO

9. FORT WORTH, TX

10. KANSAS CITY, MO

11. SAN DIEGO, CA

12. COLUMBUS, $\mathrm{OH}$

13. CINCINNATI, OH

14. MIAMI, FL

15. NASHVILLE, TN

16. VIRGINIA, VA

17. ST. LOUIS, MO

18. LONG BEACH, CA 
Data were obtained through a questionnaire mailed to the office of the chief of Police and the office of the municipal director of personnel (or an equivalent position) in 50 largest cities in the United States. The questionnaire addressed the racial demographics of the police officers employed at the police departments and the distribution of the police officers assignment to elite police specialty units within the departments. Of the 50 police departments requested to participate in the study, $18(36 \%)$ completed and returned the questionnaire, $11(22 \%)$ returned incomplete questionnaires, and $21(42 \%)$ did not reply. The level of reluctance to participate in the study was expected, due to the sensitive nature of the questionnaire and the guarded disposition of police department when race related information is requested that could possibly cause embarrassment to the police department and or expose disproportionate race related representation.

\section{BLACK POLICE OFFICER'S REPRESENTATION:}

Of the 18 police departments that replied and completed the questionnaire, the majority of the police officers employed at the police departments were white, black, and Hispanic. Although there were additional police officers representing other racial groups, they were not included in the study because of infrequent representation within the responding police departments, and the small number of police officers representing the various racial groups.

In the study, data relating to white, black, and Hispanic police officer's 
representation within the police departments and elite police specialty units were analyzed and compared for the purpose of determining if their representation was proportionate or disproportionate. This data were also compared to the local population of each city where the police departments were located in order to determine if white, black, and Hispanic police officer's were proportionate or disproportionate to the local population.

The data calculation of blacks in the local population and black police officer's representation within the police departments involved in this study, displayed an average index of $(.72)$ and a standard deviation of (.17). Of the 18 police departments which participated this study, 15 or ( $83.3 \%)$ had an index less than (1.00). See table land figure 2.

Black police officer's representation within elite police specialty units when calculated with black police officers in the department, had an average index of (1.11) with a standard deviation of (.49). Of the 18 police departments involved in this study, 8 or $(44.4 \%)$ had a black representation within elite police specialty units of $(1.00)$ or higher. See table 2 and figure 3.

When calculating the index of black police officer's representation within police specialty units and blacks in the local population, the average index was (.78) with a standard deviation of (.33). Of the 18 police departments used in this study, 15 or (83.3\%) had an index of less than (1.00). See table 3 and 1 figure 4.

WHITE POLICE OFFICER'S REPRESENTATION: 
The data calculation of whites in the local population and white police officer's representation within the 18 police departments utilized in this study displayed an average index of (1.31) with a standard deviation of (.18). Of the 18 police departments used in this study, 1 or $(5.5 \%)$ had an index less than (1.00). See table 4 and figure 5 .

An analysis of the data indicated that white police officers had an average representation index within police specialty units of (1.04) with a standard deviation of $(.15)$, when calculated with the percentage of white police officer's representation within the police departments. Of the 18 police departments involved in this study, 12 or $(66.6 \%)$ had an index of $(1.00)$ or higher. See table 5 and figure 6.

Based on the calculation of the data, the average index of white police officer's representation within elite police specialty units and whites in the local population is (1.36) with a standard deviation of (.22). Of the 18 police departments involved in this study, 17 or $(94.4 \%)$ had an index higher than (1.00). See table 6 and figure 7.

\section{HISPANIC POLICE OFFICER'S REPRESENTATION:}

An analysis of the data indicated that Hispanic police officer's representation within the police departments, when calculated with Hispanics in the local population displayed an average index of (1.12) with a standard deviation of (.64). Of the 18 police departments, 11 or $(61.1 \%)$ had an index higher than $(1.00)$. See table 7 and figure 8 . 
An analysis of the data indicated that Hispanic police officers had an average representation index within elite police specialty units of $(.70)$ with a standard deviation equaling (.43), when calculated with Hispanic representation within the police department. Of the 18 police departments, used in the study, 10 or $(66.6 \%)$ had an index below (1.00). Note: 3 police departments were not used in the calculation, due to the lack of Hispanic representation within the police department. See table 8 and figure 9.

A analyses of the data indicated that the average index of Hispanic police officer's representation within elite police specialty units, when calculated with the number of Hispanics in the local population was (.94), with a standard divination of (.43). Of the 18 police departments in the study, 10 or (55.5\%) had an index of (1.00) or higher. See table 9 and figure 10.

The majority of the police departments which provided information for the purpose of this study are located in the northeast and southwest sections of the United States. The cities in which the police departments are located have an fair representation of black, white, and Hispanic individuals within the local population. 


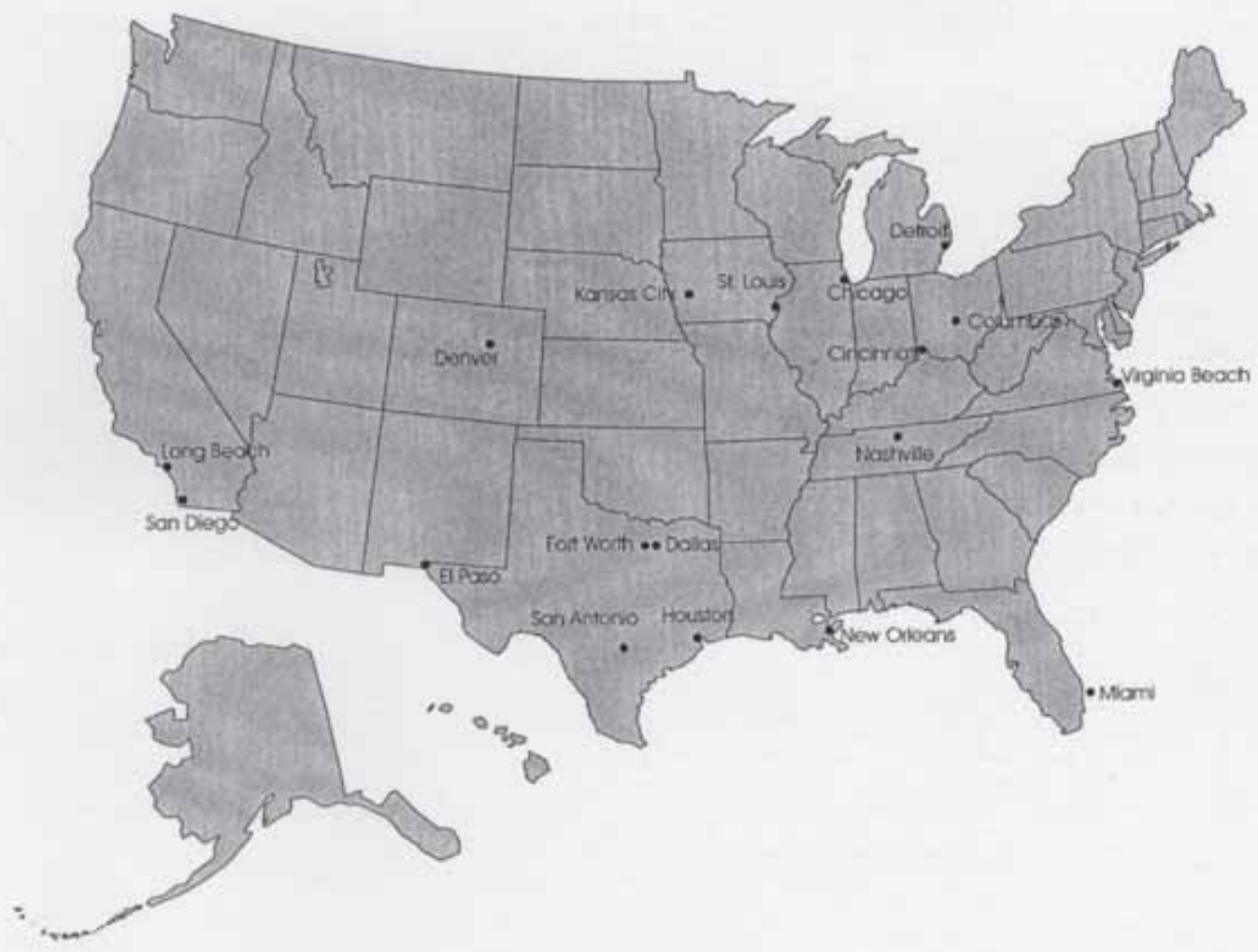

Figure 1:

Map of U.S. Cities listing respondents to surveys and Police Departments 


\begin{tabular}{|l|r|r|r|r|r|}
\hline \multicolumn{1}{|c|}{ City } & $\begin{array}{c}\text { Total } \\
\text { number of } \\
\text { officers in } \\
\text { department }\end{array}$ & $\begin{array}{c}\text { Total number } \\
\text { of black } \\
\text { officers in } \\
\text { department }\end{array}$ & $\begin{array}{c}\text { Percentage of } \\
\text { black officers } \\
\text { in department }\end{array}$ & $\begin{array}{c}\text { Percentage of } \\
\text { blacks in the } \\
\text { population }\end{array}$ & $\begin{array}{c}\text { Index of black } \\
\text { representatio } \\
\text { n within the } \\
\text { department }\end{array}$ \\
\hline Chicago & 13,796 & 3,554 & $25.8 \%$ & $38.5 \%$ & 0.67 \\
\hline Houston & 5,429 & 1,043 & $19.2 \%$ & $27.4 \%$ & 0.7 \\
\hline Detroit & 4,033 & 3,135 & $77.8 \%$ & $75.3 \%$ & 1.03 \\
\hline Dallas & 2,859 & 603 & $21.0 \%$ & $28.8 \%$ & 0.72 \\
\hline $\begin{array}{l}\text { San } \\
\text { Antonio }\end{array}$ & 1,882 & 110 & $5.8 \%$ & $6.7 \%$ & 0.86 \\
\hline El Paso & 1,024 & 23 & $2.1 \%$ & $3.1 \%$ & 0.67 \\
\hline $\begin{array}{l}\text { New } \\
\text { Orleans }\end{array}$ & 1,664 & 856 & $51.4 \%$ & $61.3 \%$ & 0.83 \\
\hline Denver & 1,449 & 145 & $9.9 \%$ & $12.3 \%$ & 0.8 \\
\hline $\begin{array}{l}\text { Fort } \\
\text { Worth }\end{array}$ & 1,165 & 137 & $11.7 \%$ & $21.6 \%$ & 0.54 \\
\hline $\begin{array}{l}\text { Kansas } \\
\text { City }\end{array}$ & 1,258 & 152 & $12.0 \%$ & $29.4 \%$ & 0.4 \\
\hline San Diego & 2,065 & 180 & $8.7 \%$ & $8.9 \%$ & 0.97 \\
\hline Columbus & 1,779 & 251 & $14.1 \%$ & $22.4 \%$ & 0.62 \\
\hline Cincinnati & 1,058 & 296 & $27.9 \%$ & $37.8 \%$ & 0.73 \\
\hline Miami & 1,117 & 305 & $27.3 \%$ & $24.6 \%$ & 1.1 \\
\hline Nashville & 1,231 & 165 & $13.4 \%$ & $24.1 \%$ & 0.54 \\
\hline $\begin{array}{l}\text { Virginia } \\
\text { Beach }\end{array}$ & 725 & 64 & $8.8 \%$ & $13.6 \%$ & 0.64 \\
\hline St. Louis & 1,576 & 506 & $33.3 \%$ & $47.3 \%$ & 0.7 \\
\hline $\begin{array}{l}\text { Long } \\
\text { Beach }\end{array}$ & 855 & 58 & $6.7 \%$ & $13.2 \%$ & 0.5 \\
\hline
\end{tabular}

TABLE 1: Index of black representation in Police Departments.

Note:

Data were obtained through a questionnaire mailed to the office of the Chief of Police or the office of the municipal Director of personnel (or equivalent) in the 50 largest cities in the United States. Eighteen (18) cities or $36 \%$ returned completed questionnaires. The index of black representation is calculated by dividing the percent of black officers in a police department by the percent of blacks $n$ the local population. An index approaching 1.0 indicates that a police department and or city is closer to achieving a representation of black police officers equal to their proportion in the local population. The black population of a city is derived from the 1990 census of the population. 


\begin{tabular}{|l|r|r|r|r|r|}
\hline \multicolumn{1}{|c|}{ City } & $\begin{array}{r}\text { Total } \\
\text { Number of } \\
\text { Officers in } \\
\text { Specialty } \\
\text { Units }\end{array}$ & $\begin{array}{r}\text { Number of } \\
\text { black } \\
\text { officers in } \\
\text { Specialty } \\
\text { Units }\end{array}$ & $\begin{array}{r}\text { Percentage } \\
\text { of black } \\
\text { officers in } \\
\text { Specialty } \\
\text { Units }\end{array}$ & $\begin{array}{r}\text { Total } \\
\text { number of } \\
\text { black officers } \\
\text { in } \\
\text { Department }\end{array}$ & $\begin{array}{r}\text { Index of black } \\
\text { representation } \\
\text { within the } \\
\text { Specialty } \\
\text { Units }\end{array}$ \\
\hline Chicago & 1,635 & 468 & $28.5 \%$ & 3,554 & 1.10 \\
\hline Houston & 699 & 168 & $24.0 \%$ & 1,043 & 1.25 \\
\hline Detroit & 1,622 & 1,165 & $71.8 \%$ & 3,135 & 0.92 \\
\hline Dallas & 459 & 69 & $15.0 \%$ & 603 & 0.71 \\
\hline San Antonio & 260 & 19 & $7.3 \%$ & 110 & 1.37 \\
\hline New Orleans & 154 & 67 & $45.4 \%$ & 23 & 0.88 \\
\hline Denver & 170 & 15 & $8.8 \%$ & 856 & 0.88 \\
\hline Fort Worth & 96 & 15 & $15.2 \%$ & 145 & 1.29 \\
\hline Kansas City & 403 & 48 & $11.9 \%$ & 137 & 0.99 \\
\hline San Diego & 212 & 12 & $5.6 \%$ & 152 & 0.64 \\
\hline Columbus & 140 & 23 & $16.4 \%$ & 180 & 1.16 \\
\hline Cincinnati & 289 & 60 & $20.7 \%$ & 251 & 0.75 \\
\hline Miami & 374 & 80 & $21.4 \%$ & 296 & 0.78 \\
\hline Nashville & 409 & 58 & $14.1 \%$ & 305 & 1.05 \\
\hline Virginia & & & & & \\
Beach & 45 & 10 & $22.2 \%$ & 165 & 2.52 \\
\hline St. Louis & 545 & 181 & $33.1 \%$ & 64 & 0.99 \\
\hline Long Beach & 153 & 6 & $3.9 \%$ & 506 & 0.58 \\
\hline El Paso & 127 & 6 & $4.7 \%$ & 58 & 2.23 \\
\hline
\end{tabular}

TABLE 2: Index of black representation in police specialty units.

Note:

Data were obtained through a questionnaire mailed to the office of the Chief of Police or the office of the municipal Director of personnel (or equivalent) in the 50 largest cities in the United States. Eighteen (18) cities or $36 \%$ returned completed questionnaires. The index of black representation is calculated by dividing the percent of black officers in police specialty units by the percent of black police officers in the police department. An index approaching 1.0 indicates that a police department and or city is closer to achieving a representation of black police officers assigned to elite specialty units equal to their proportion in the police department. The black population of a city is derived from the 1990 census of the population. 


\begin{tabular}{|l|r|r|r|r|r|}
\hline \multicolumn{1}{|c|}{ City } & $\begin{array}{r}\text { Total } \\
\text { Number of } \\
\text { Officers in } \\
\text { Specialty } \\
\text { Units }\end{array}$ & $\begin{array}{r}\text { Tumber of } \\
\text { black } \\
\text { officers in } \\
\text { Specialty } \\
\text { Units }\end{array}$ & $\begin{array}{r}\text { Percentage } \\
\text { of black } \\
\text { officers in } \\
\text { Specialty } \\
\text { Units }\end{array}$ & $\begin{array}{r}\text { Percentage } \\
\text { of blacks in } \\
\text { the } \\
\text { population }\end{array}$ & $\begin{array}{r}\text { Index of black } \\
\text { reprentation } \\
\text { within the } \\
\text { department }\end{array}$ \\
\hline Chicago & 1,635 & 468 & $28.5 \%$ & $38.5 \%$ & 0.74 \\
\hline Houston & 699 & 168 & $24.0 \%$ & $27.4 \%$ & 0.87 \\
\hline Detroit & 1,622 & 1,165 & $71.8 \%$ & $75.3 \%$ & 0.95 \\
\hline Dallas & 459 & 69 & $15.0 \%$ & $28.8 \%$ & 0.53 \\
\hline San Antonio & 260 & 19 & $7.3 \%$ & $6.7 \%$ & 1.08 \\
\hline New Orleans & 154 & 67 & $45.4 \%$ & $3.1 \%$ & 0.74 \\
\hline Denver & 170 & 15 & $8.8 \%$ & $61.3 \%$ & 0.71 \\
\hline Fort Worth & 96 & 15 & $15.2 \%$ & $12.3 \%$ & 0.7 \\
\hline Kansas City & 403 & 48 & $11.9 \%$ & $21.6 \%$ & 0.4 \\
\hline San Diego & 212 & 12 & $5.6 \%$ & $29.4 \%$ & 0.62 \\
\hline Columbus & 140 & 23 & $16.4 \%$ & $8.9 \%$ & 0.73 \\
\hline Cincinnati & 289 & 60 & $20.7 \%$ & $22.4 \%$ & 0.54 \\
\hline Miami & 374 & 80 & $21.4 \%$ & $37.8 \%$ & 0.86 \\
\hline Nashville & 409 & 58 & $14.1 \%$ & $24.6 \%$ & 0.58 \\
\hline Virginia & & & & $24 \%$ & 1.63 \\
Beach & 45 & 10 & $22.2 \%$ & $24.1 \%$ & 0.69 \\
\hline St. Louis & 545 & 181 & $33.1 \%$ & $13.6 \%$ & 0.29 \\
\hline Long Beach & 153 & 6 & $3.9 \%$ & $47.3 \%$ & 1.51 \\
\hline El Paso & 127 & 6 & $4.7 \%$ & $13.2 \%$ & \\
\hline & & & & & \\
\hline
\end{tabular}

TABLE 3: Index of black representation in police specialty units calculated with the local population.

Note:

Data were obtained through a questionnaire mailed to the office of the Chief of Police or the office of the municipal Director of personnel (or equivalent) in the 50 largest cities in the United States. Eighteen (18) cities or $36 \%$ returned completed questionnaires. The index of black representation is calculated by dividing the percent of black officers in elite police specialty units by the percent of blacks in the local population. An index approaching 1.0 indicates that a police department and or city is closer to achieving a representation of black police officers assigned to elite specialty units equal to their proportion in the local population. The black population of a city is derived from the 1990 census of the population. 


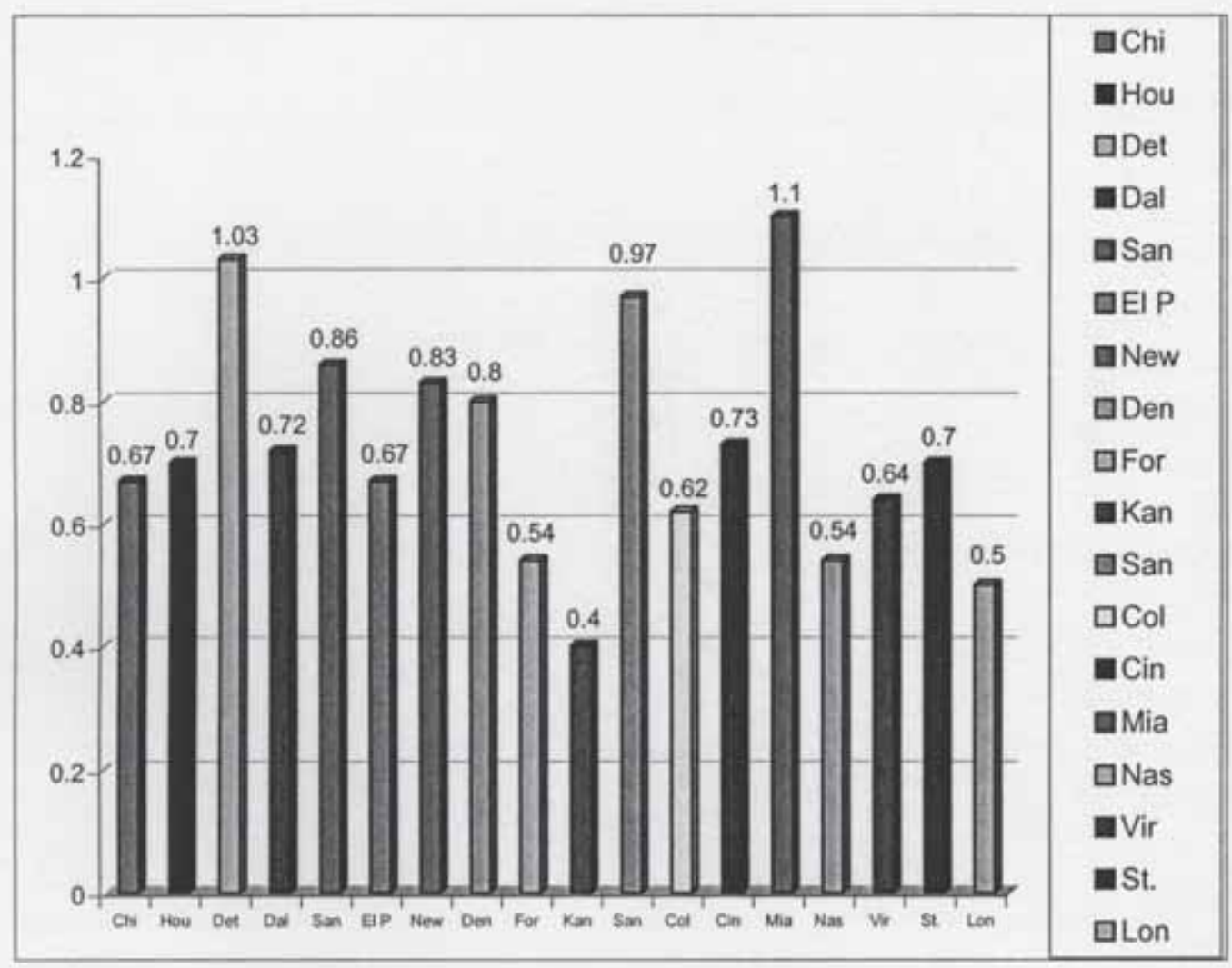

FIGURE 2: Index of black representation within police departments.

Note:

Data were obtained through a questionnaire mailed to the office of the Chief of Police or the office of the municipal Director of personnel (or equivalent) in the 50 largest cities in the United States. Eighteen (18) cities or $36 \%$ returned completed questionnaires. The index of black representation is calculated by dividing the percent of black officers in a police department by the percent of blacks n the local population. An index approaching 1.0 indicates that a police department and or city is closer to achieving a representation of black police officers equal to their proportion in the local population. The black population of a city is derived from the 1990 census of the population. 


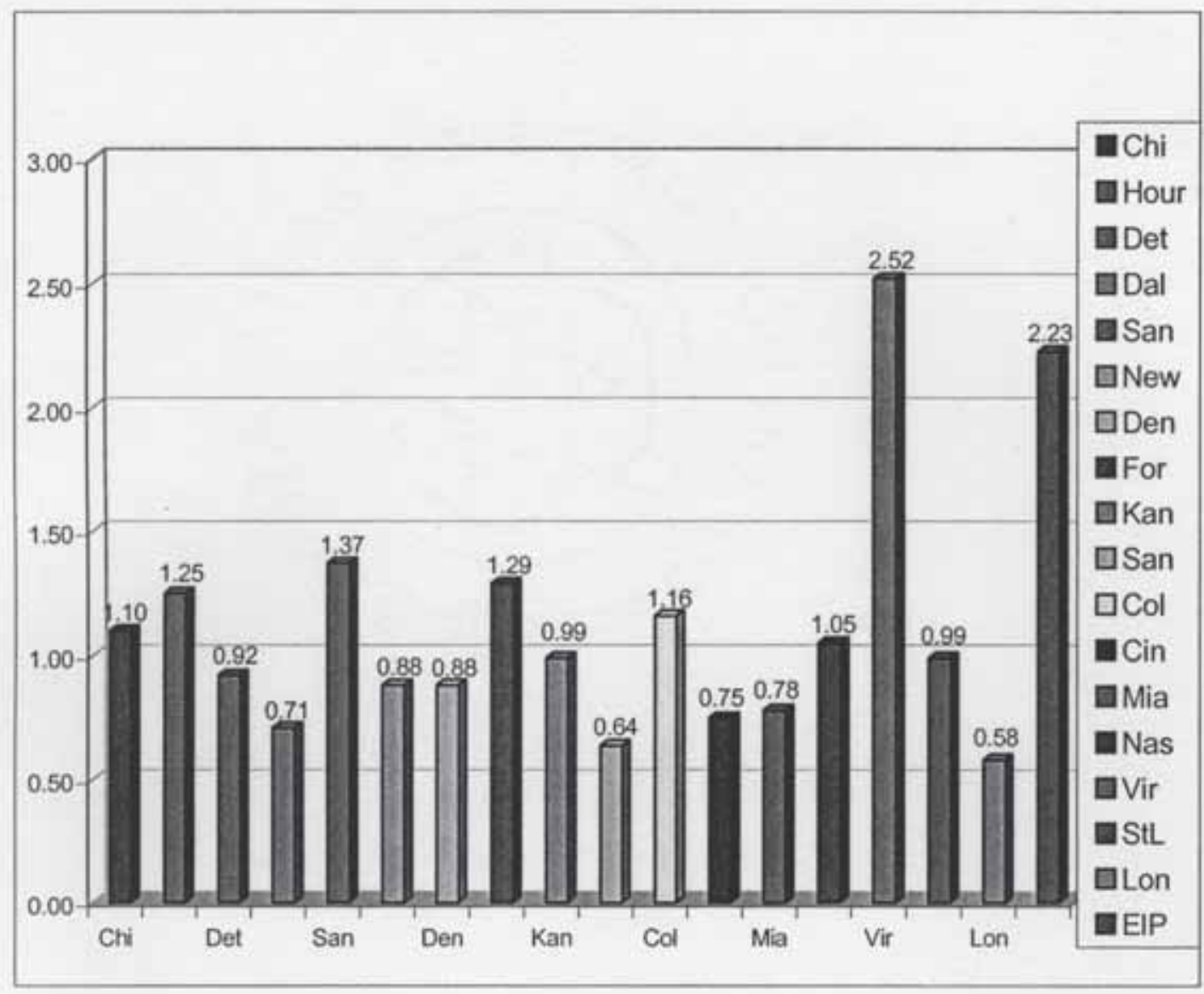

FIGURE 3: Index of black representation within specialty units compared to police departments.

Note:

Data were obtained through a questionnaire mailed to the office of the Chief of Police or the office of the municipal Director of personnel (or equivalent) in the 50 largest cities in the United States. Eighteen (18) cities or $36 \%$ returned completed questionnaires. The index of black representation is calculated by dividing the percent of black officers in police specialty units by the percent of black police officers in the police department. An index approaching 1.0 indicates that a police department and or city is closer to achieving a representation of black police officers assigned to elite specialty units equal to their proportion in the police department. The black population of a city is derived from the 1990 census of the population. 


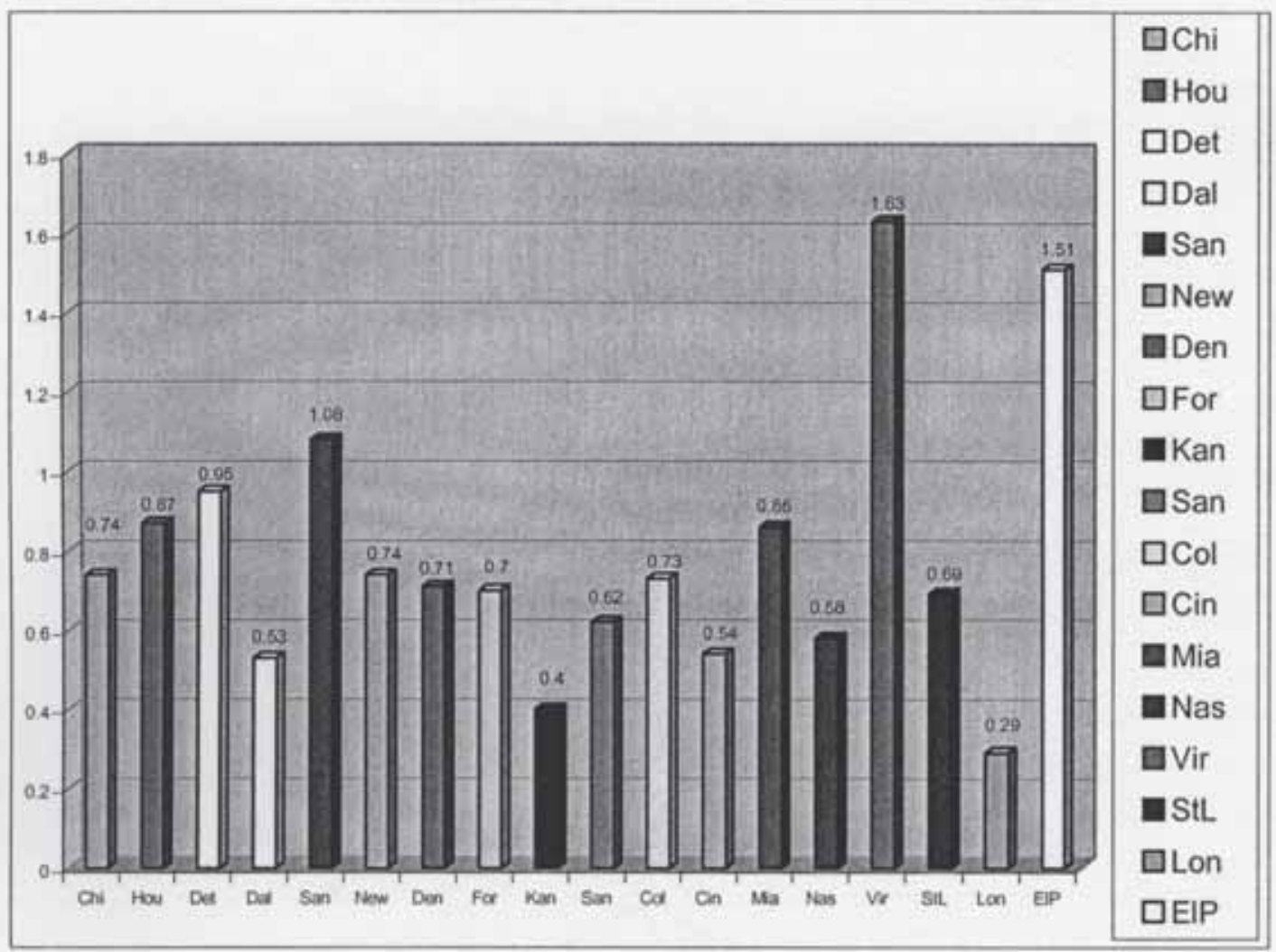

FIGURE 4: Index of black representation within specialty units compared to local population.

Note:

Data were obtained through a questionnaire mailed to the office of the Chief of Police or the office of the municipal Director of personnel (or equivalent) in the 50 largest cities in the United States. Eighteen (18) cities or $36 \%$ returned completed questionnaires. The index of black representation is calculated by dividing the percent of black officers in elite police specialty units by the percent of blacks in the local population. An index approaching 1.0 indicates that a police department and or city is closer to achieving a representation of black police officers assigned to elite specialty units equal to their proportion in the local population. The black population of a city is derived from the 1990 census of the population. 


\begin{tabular}{|l|r|r|r|r|r|}
\hline \multicolumn{1}{|c|}{ City } & $\begin{array}{r}\text { Total } \\
\text { Total Number } \\
\text { of Officers in } \\
\text { Departments }\end{array}$ & $\begin{array}{r}\text { Number of } \\
\text { White } \\
\text { officers in } \\
\text { Department }\end{array}$ & $\begin{array}{r}\text { Percentage } \\
\text { of white } \\
\text { officers in } \\
\text { department }\end{array}$ & $\begin{array}{r}\text { Percentage } \\
\text { of whites in } \\
\text { the } \\
\text { population }\end{array}$ & $\begin{array}{r}\text { Index of white } \\
\text { reprentation } \\
\text { within the } \\
\text { department }\end{array}$ \\
\hline Chicago & 13,796 & 8,322 & $60.4 \%$ & $37.9 \%$ & 1.59 \\
\hline Houston & 5,429 & 3,301 & $60.8 \%$ & $40.6 \%$ & 1.49 \\
\hline Detroit & 4,033 & 1,427 & $35.3 \%$ & $20.6 \%$ & 1.71 \\
\hline Dallas & 2,859 & 1,819 & $63.6 \%$ & $47.6 \%$ & 1.33 \\
\hline $\begin{array}{l}\text { San } \\
\text { Antonio }\end{array}$ & 1,882 & & & & \\
\hline $\begin{array}{l}\text { New } \\
\text { Orleans }\end{array}$ & 1,024 & 978 & $51.9 \%$ & $36.2 \%$ & 1.43 \\
\hline Denver & 1,664 & 1,016 & $70.1 \%$ & $61.4 \%$ & 1.38 \\
\hline $\begin{array}{l}\text { Fort } \\
\text { Worth }\end{array}$ & 1,449 & 892 & $46.5 \%$ & $56.4 \%$ & 1.14 \\
\hline $\begin{array}{l}\text { Kansas } \\
\text { City }\end{array}$ & 1,165 & 1,048 & $83.3 \%$ & $64.9 \%$ & 1.35 \\
\hline San Diego & 1,258 & 1,439 & $69.6 \%$ & $56.6 \%$ & 1.28 \\
\hline Columbus & 2,065 & 1,528 & $85.8 \%$ & $73.8 \%$ & 1.22 \\
\hline Cincinnati & 1,779 & 749 & $70.7 \%$ & $60.1 \%$ & 1.16 \\
\hline Miami & 1,058 & 210 & $18.8 \%$ & $12.2 \%$ & 1.17 \\
\hline Nashville & 1,117 & 1,038 & $84.3 \%$ & $73.2 \%$ & 1.54 \\
\hline $\begin{array}{l}\text { Virginia } \\
\text { Beach }\end{array}$ & 1,231 & 625 & $86.2 \%$ & $78.8 \%$ & 1.15 \\
\hline St. Louis & 725 & 1,040 & $65.9 \%$ & $50.1 \%$ & 1.09 \\
\hline $\begin{array}{l}\text { Long } \\
\text { Beach }\end{array}$ & 1,576 & 580 & $67.9 \%$ & $49.5 \%$ & 1.31 \\
\hline El Paso & 855 & 256 & $25.0 \%$ & $26.3 \%$ & 1.37 \\
\hline
\end{tabular}

TABLE 4: Index of white representation in police departments.

Note:

Data were obtained through a questionnaire mailed to the office of the Chief of Police or the office of the municipal Director of personnel (or equivalent) in the 50 largest cities in the United States. Eighteen (18) cities or $36 \%$ returned completed questionnaires. The index of white representation is calculated by dividing the percent of white police officers in a police department by the percent of whites in the local population. An index approaching 1.0 indicates that a police department and or city is closer to achieving a representation of white police officers equal to their proportion in the local population. The white population of a city is derived from the 1990 census of the population. 


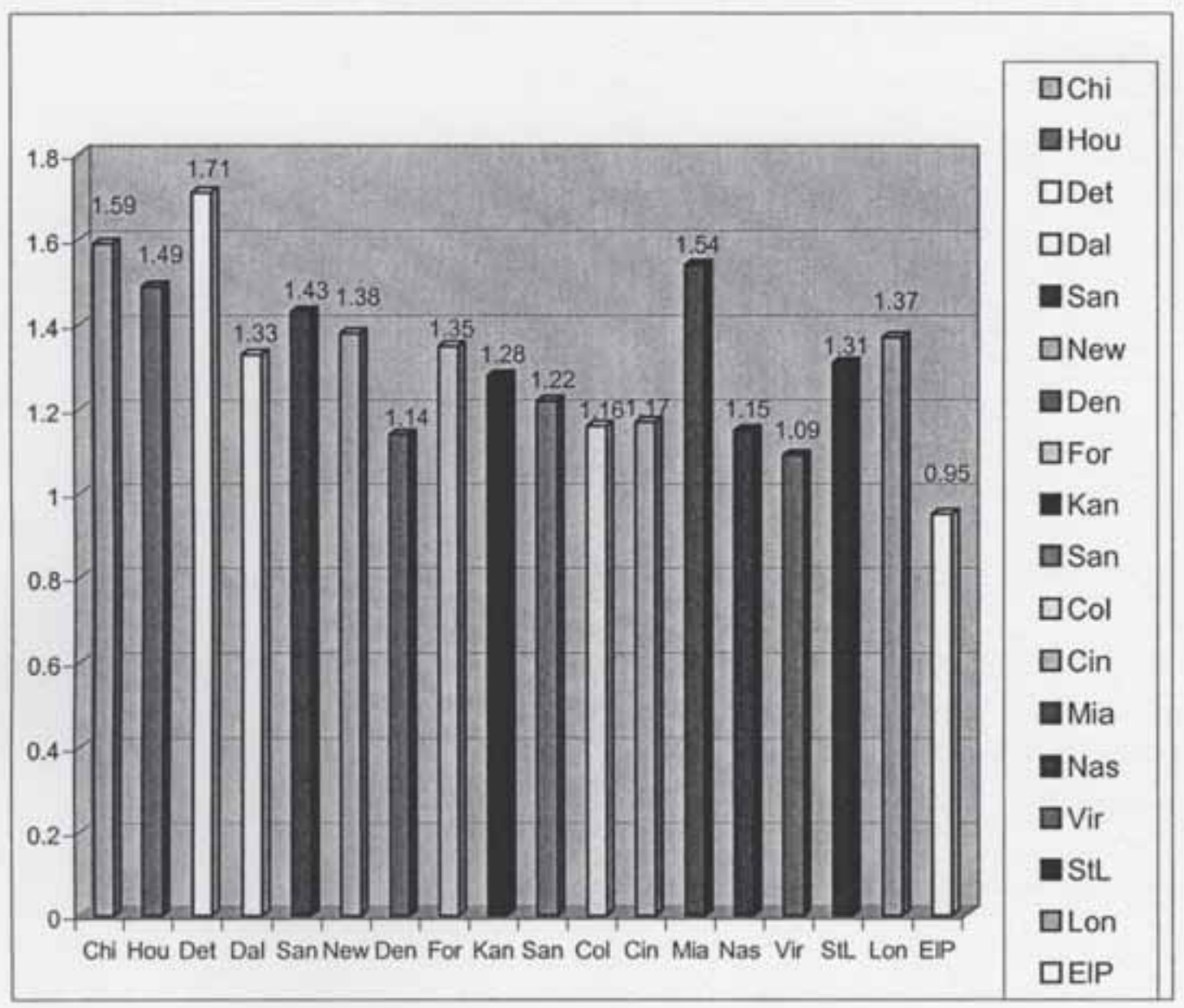

FIGURE 5: Index of white representation in police departments

Note:

Data were obtained through a questionnaire mailed to the office of the Chief of Police or the office of the municipal Director of personnel (or equivalent) in the 50 largest cities in the United States. Eighteen (18) cities or $36 \%$ returned completed questionnaires. The index of white representation is calculated by dividing the percent of white police officers in a police department by the percent of whites in the local population. An index approaching 1.0 indicates that a police department and or city is closer to achieving a representation of white police officers equal to their proportion in the local population. The white population of a city is derived from the 1990 census of the population. 


\begin{tabular}{|c|c|c|c|c|c|c|}
\hline City & $\begin{array}{r}\text { Total } \\
\text { Number } \\
\text { of } \\
\text { Officers } \\
\text { in } \\
\text { Specialty } \\
\text { Units }\end{array}$ & $\begin{array}{r}\text { Total } \\
\text { Number } \\
\text { of white } \\
\text { officers in } \\
\begin{array}{r}\text { Specialty } \\
\text { Units }\end{array}\end{array}$ & $\begin{array}{r}\text { Percentage } \\
\text { of white } \\
\text { officers in } \\
\text { Specialty } \\
\text { Units }\end{array}$ & $\begin{array}{r}\text { Total } \\
\text { Number of } \\
\text { white } \\
\text { officers in } \\
\text { Department }\end{array}$ & $\begin{array}{r}\text { Percentage } \\
\text { of white } \\
\text { officers in } \\
\text { department }\end{array}$ & $\begin{array}{r}\text { Index of white } \\
\text { representation } \\
\text { within the } \\
\text { Specialty } \\
\text { Units }\end{array}$ \\
\hline Chicago & 1,635 & 1,003 & $61.3 \%$ & 8,322 & $60.4 \%$ & 1.61 \\
\hline Houston & 699 & 398 & $56.9 \%$ & 3,301 & $60.8 \%$ & 1.4 \\
\hline Detroit & 1,622 & 417 & $25.7 \%$ & 1,427 & $35.3 \%$ & 1.24 \\
\hline Dallas & 459 & 339 & $73.8 \%$ & 1,819 & $63.6 \%$ & 1.55 \\
\hline $\begin{array}{l}\text { San } \\
\text { Antonio }\end{array}$ & 260 & 122 & $46.9 \%$ & 978 & $51.9 \%$ & 1.29 \\
\hline $\begin{array}{l}\text { New } \\
\text { Orleans }\end{array}$ & 154 & 84 & $54.5 \%$ & 765 & $45.9 \%$ & 1.64 \\
\hline Denver & 170 & 122 & $71.7 \%$ & 1,016 & $70.1 \%$ & 1.16 \\
\hline $\begin{array}{l}\text { Fort } \\
\text { Worth }\end{array}$ & 96 & 68 & $70.8 \%$ & 892 & $46.5 \%$ & 1.25 \\
\hline $\begin{array}{l}\text { Kansas } \\
\text { City }\end{array}$ & 403 & 349 & $86.5 \%$ & 1,048 & $83.3 \%$ & 1.33 \\
\hline $\begin{array}{l}\text { San } \\
\text { Diego }\end{array}$ & 212 & 168 & $79.2 \%$ & 1,439 & $69.6 \%$ & 1.39 \\
\hline Columbus & 140 & 117 & $83.5 \%$ & 1,528 & $85.8 \%$ & 1.13 \\
\hline Cincinnati & 289 & 229 & $79.2 \%$ & 749 & $70.7 \%$ & 1.31 \\
\hline Miami & 374 & 90 & $24.0 \%$ & 210 & $18.8 \%$ & 1.96 \\
\hline Nashville & 409 & 351 & $85.8 \%$ & 1,038 & $84.3 \%$ & 1.17 \\
\hline $\begin{array}{l}\text { Virginia } \\
\text { Beach }\end{array}$ & 45 & 34 & $75.5 \%$ & 625 & $86.2 \%$ & 0.95 \\
\hline St. Louis & 545 & 360 & $66.0 \%$ & 1,040 & $65.9 \%$ & 1.31 \\
\hline $\begin{array}{l}\text { Long } \\
\text { Beach }\end{array}$ & 153 & 119 & $77.7 \%$ & 580 & $67.9 \%$ & 1.56 \\
\hline El Paso & 127 & 46 & $36.2 \%$ & 256 & $25.0 \%$ & 1.37 \\
\hline
\end{tabular}

Table 5: Index of white representation in police specialty units.

Note:

Data were obtained through a questionnaire mailed to the office of the Chief of Police or the office of the municipal Director of personnel (or equivalent) in the 50 largest cities in the United States. Eighteen (18) cities or $36 \%$ returned completed questionnaires. The index of white representation is calculated by dividing the percent of white officers in elite police specialty units by the percent of white police officers in the police department. An index approaching 1.0 indicates that a police department and or city is closer to achieving a representation of white police officers assigned to elite specialty units equal to their proportion in the police department. The white population of a city is derived from the 1990 census of the population. 


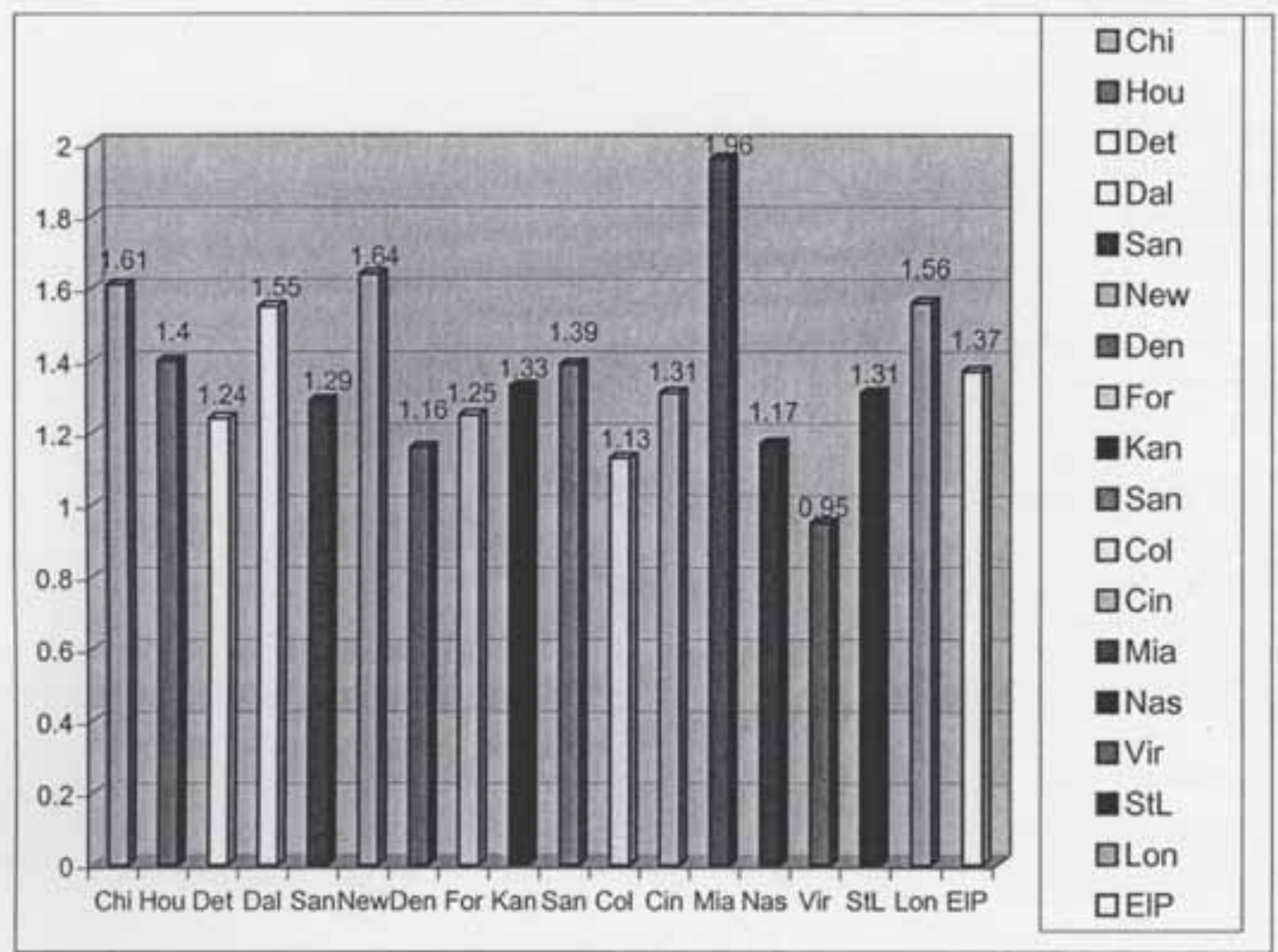

Figure 6: Index of white representation in specialty units compared to police departments.

Note:

Data were obtained through a questionnaire mailed to the office of the Chief of Police or the office of the municipal Director of personnel (or equivalent) in the 50 largest cities in the United States. Eighteen (18) cities or $36 \%$ returned completed questionnaires. The index of white representation is calculated by dividing the percent of white officers in elite police specialty units by the percent of white police officers in the police department. An index approaching 1.0 indicates that a police department and or city is closer to achieving a representation of white police officers assigned to elite specialty units equal to their proportion in the police department. The white population of a city is derived from the 1990 census of the population. 


\begin{tabular}{|c|c|c|c|c|c|}
\hline City & $\begin{array}{r}\text { Total } \\
\text { Number of } \\
\text { Officers in } \\
\text { Specialty } \\
\text { Units }\end{array}$ & $\begin{array}{r}\text { Total } \\
\text { Number of } \\
\text { white } \\
\text { officers in } \\
\text { Specialty } \\
\text { Units }\end{array}$ & $\begin{array}{r}\text { Percentage } \\
\text { of white } \\
\text { officers in } \\
\text { Specialty } \\
\text { Units }\end{array}$ & $\begin{array}{r}\text { Percentage of } \\
\text { white in the } \\
\text { population }\end{array}$ & $\begin{array}{l}\text { Index of white } \\
\text { representation } \\
\text { within the } \\
\text { Specialty Units }\end{array}$ \\
\hline Chicago & 1,635 & 1,003 & $61.3 \%$ & $37.9 \%$ & 1.61 \\
\hline Houston & 699 & 398 & $56.9 \%$ & $40.6 \%$ & 1.4 \\
\hline Detroit & 1,622 & 417 & $25.7 \%$ & $20.6 \%$ & 1.24 \\
\hline Dallas & 459 & 339 & $73.8 \%$ & $47.6 \%$ & 1.55 \\
\hline $\begin{array}{l}\text { San } \\
\text { Antonio }\end{array}$ & 260 & 122 & $46.9 \%$ & $36.2 \%$ & 1.29 \\
\hline $\begin{array}{l}\text { New } \\
\text { Orleans }\end{array}$ & 154 & 84 & $54.5 \%$ & $33.1 \%$ & 1.64 \\
\hline Denver & 170 & 122 & $71.7 \%$ & $61.4 \%$ & 1.16 \\
\hline Fort Worth & 96 & 68 & $70.8 \%$ & $56.4 \%$ & 1.25 \\
\hline Kansas City & 403 & 349 & $86.5 \%$ & $64.9 \%$ & 1.33 \\
\hline San Diego & 212 & 168 & $79.2 \%$ & $56.6 \%$ & 1.39 \\
\hline Columbus & 140 & 117 & $83.5 \%$ & $73.8 \%$ & 1.13 \\
\hline Cincinnati & 289 & 229 & $79.2 \%$ & $60.1 \%$ & 1.31 \\
\hline Miami & 374 & 90 & $24.0 \%$ & $12.2 \%$ & 1.96 \\
\hline Nashville & 409 & 351 & $85.8 \%$ & $73.2 \%$ & 1.17 \\
\hline $\begin{array}{l}\text { Virginia } \\
\text { Beach }\end{array}$ & 45 & 34 & $75.5 \%$ & $78.8 \%$ & 0.95 \\
\hline St. Louis & 545 & 360 & $66.0 \%$ & $50.1 \%$ & 1.31 \\
\hline Long Beach & 153 & 119 & $77.7 \%$ & $49.5 \%$ & 1.56 \\
\hline El Paso & 127 & 46 & $36.2 \%$ & $26.3 \%$ & 1.37 \\
\hline
\end{tabular}

TABLE 6: Index of white representation in police specialty units calculated with the local population.

Note:

Data were obtained through a questionnaire mailed to the office of the Chief of Police or the office of the municipal Director of personnel (or equivalent) in the 50 largest cities in the United States. Eighteen (18) cities or $36 \%$ returned completed questionnaires. The index of white representation is calculated by dividing the percent of white officers in elite police specialty units by the percent of whites in the local population. An index approaching 1.0 indicates that a police department and or city is closer to achieving a representation of white police officers assigned to elite specialty units equal to their proportion in the local population. The white population of a city is derived from the 1990 census of the population. 


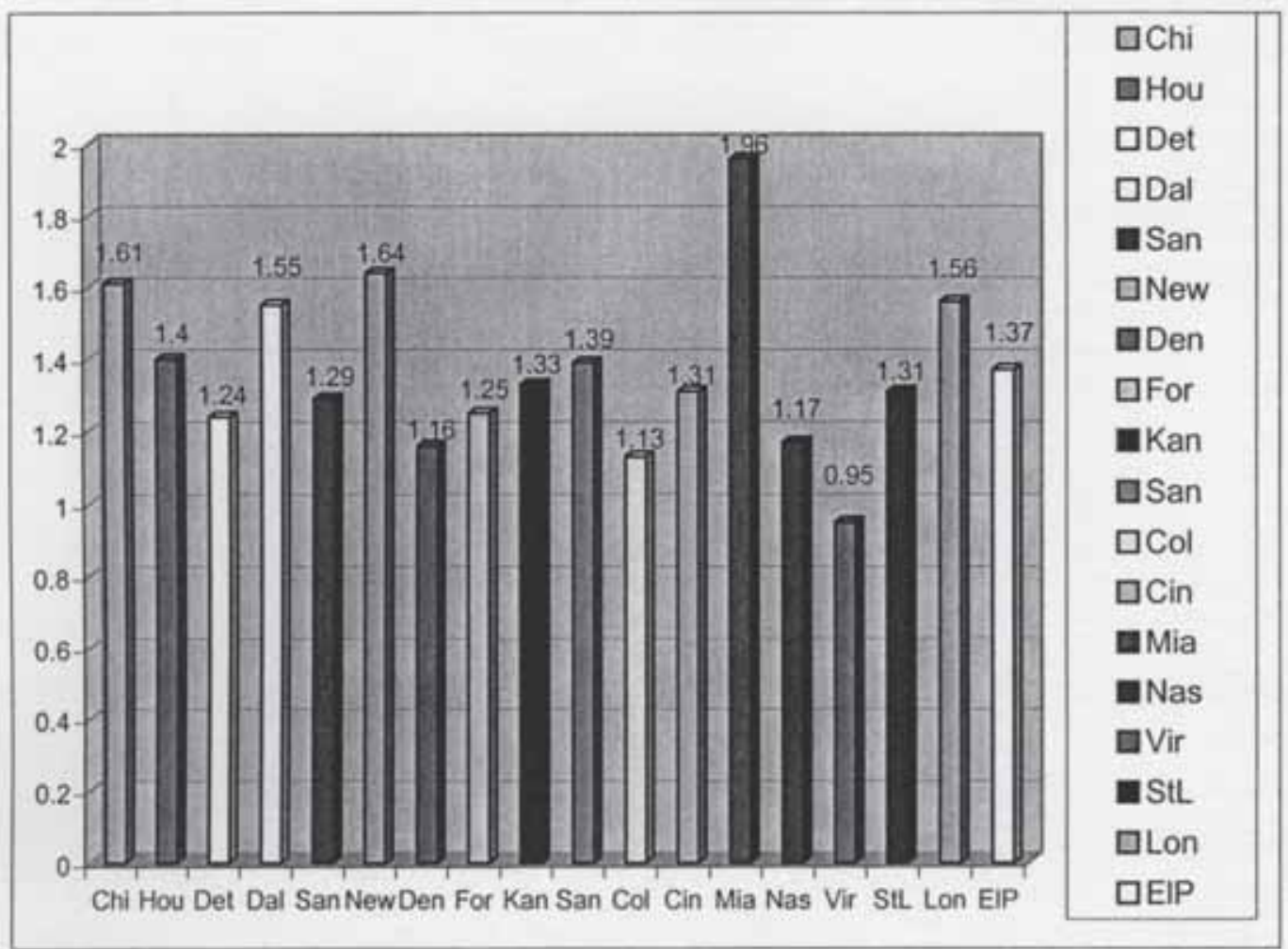

FIGURE 7: Index of white representation in police specialty units calculated with the local population.

Note:

Data were obtained through a questionnaire mailed to the office of the Chief of Police or the office of the municipal Director of personnel (or equivalent) in the 50 largest cities in the United States. Eighteen (18) cities or $36 \%$ returned completed questionnaires. The index of white representation is calculated by dividing the percent of white officers in elite police specialty units by the percent of whites in the local population. An index approaching 1.0 indicates that a police department and or city is closer to achieving a representation of white police officers assigned to elite specialty units equal to their proportion in the local population. The white population of a city is derived from the 1990 census of the population. 


\begin{tabular}{|l|r|r|r|r|r|}
\hline \multicolumn{1}{|c|}{ City } & $\begin{array}{r}\text { Total } \\
\text { Number of } \\
\text { Officers in } \\
\text { Department }\end{array}$ & $\begin{array}{r}\text { Number of } \\
\text { Hispanic } \\
\text { officers in } \\
\text { Department }\end{array}$ & $\begin{array}{r}\text { Percentage } \\
\text { of Hispanic } \\
\text { officers in } \\
\text { the } \\
\text { department }\end{array}$ & $\begin{array}{r}\text { Percentage } \\
\text { of Hispanic } \\
\text { in the } \\
\text { population }\end{array}$ & $\begin{array}{r}\text { representation } \\
\text { within the } \\
\text { department }\end{array}$ \\
\hline Chicago & 13,796 & 1,668 & $12.1 \%$ & $8.1 \%$ & 1.49 \\
\hline Houston & 5,429 & 957 & $17.6 \%$ & $20.9 \%$ & 0.84 \\
\hline Detroit & 4,033 & 129 & $3.1 \%$ & $1.3 \%$ & 2.38 \\
\hline Dallas & 2,859 & 382 & $13.3 \%$ & $8.4 \%$ & 1.58 \\
\hline $\begin{array}{l}\text { San } \\
\text { Antonio }\end{array}$ & 1,882 & 784 & $41.6 \%$ & $36.5 \%$ & 1.13 \\
\hline $\begin{array}{l}\text { New } \\
\text { Orleans }\end{array}$ & 1,024 & 32 & $1.9 \%$ & $2.5 \%$ & 0.76 \\
\hline Denver & 1,664 & 269 & $18.5 \%$ & $11.7 \%$ & 1.58 \\
\hline Fort Worth & 1,449 & 123 & $10.5 \%$ & $7.8 \%$ & 1.34 \\
\hline $\begin{array}{l}\text { Kansas } \\
\text { City }\end{array}$ & 1,165 & 46 & $3.6 \%$ & $2.0 \%$ & 1.8 \\
\hline San Diego & 1,258 & 325 & $15.7 \%$ & $9.7 \%$ & 1.61 \\
\hline Columbus & 2,065 & 0 & $0.0 \%$ & $78.0 \%$ & 0 \\
\hline Cincinnati & 1,779 & 0 & $0.0 \%$ & $51.0 \%$ & 0 \\
\hline Miami & 1,058 & 596 & $53.3 \%$ & $56.3 \%$ & 0.94 \\
\hline Nashville & 1,117 & 0 & $0.0 \%$ & $69.0 \%$ & 0 \\
\hline $\begin{array}{l}\text { Virginia } \\
\text { Beach }\end{array}$ & 1,231 & 12 & $1.6 \%$ & $2.2 \%$ & 0.72 \\
\hline St. Louis & 725 & 17 & $1.0 \%$ & $98.0 \%$ & 1.02 \\
\hline $\begin{array}{l}\text { Long } \\
\text { Beach }\end{array}$ & 1,576 & 154 & $18.0 \%$ & $10.1 \%$ & 1.78 \\
\hline El Paso & 855 & 726 & $70.8 \%$ & $51.8 \%$ & 1.36 \\
\hline
\end{tabular}

TABLE 7: Index of Hispanic representation in police departments.

Note:

Data were obtained through a questionnaire mailed to the office of the Chief of Police or the office of the municipal Director of personnel (or equivalent) in the 50 largest cities in the United States. Eighteen (18) cities or $36 \%$ returned completed questionnaires. The index of Hispanic representation is calculated by dividing the percent of Hispanic officers in a police department by the percent of Hispanics in the local population. An index approaching 1.0 indicates that a police department and or city is closer to achieving a representation of Hispanic police officers equal to their proportion in the local population. The Hispanic population of a city is derived from the 1990 census of the population. 


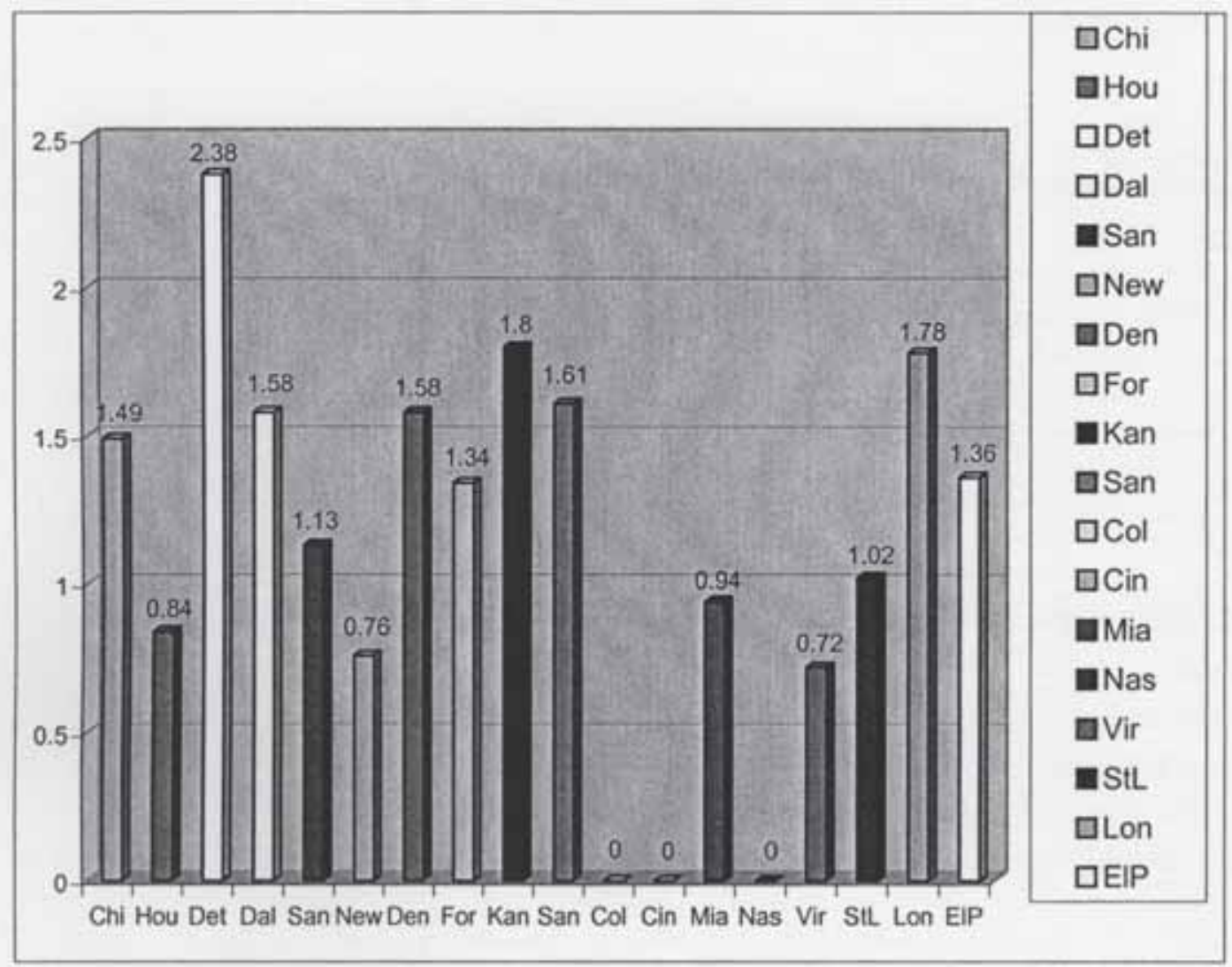

FIGURE 8: Index of Hispanic representation in police departments.

Note:

Data were obtained through a questionnaire mailed to the office of the Chief of Police or the office of the municipal Director of personnel (or equivalent) in the 50 largest cities in the United States. Eighteen (18) cities or $36 \%$ returned completed questionnaires. The index of Hispanic representation is calculated by dividing the percent of Hispanic officers in a police department by the percent of Hispanics in the local population. An index approaching 1.0 indicates that a police department and or city is closer to achieving a representation of Hispanic police officers equal to their proportion in the local population. The Hispanic population of a city is derived from the 1990 census of the population. 


\begin{tabular}{|c|c|c|c|c|c|c|}
\hline City & $\begin{array}{r}\text { Total } \\
\text { Number } \\
\text { of } \\
\text { Officers } \\
\text { in } \\
\text { Specialty } \\
\text { Units }\end{array}$ & $\begin{array}{r}\text { Total } \\
\text { Number } \\
\text { of } \\
\text { Hispanic } \\
\text { officers } \\
\text { in } \\
\text { Specialty } \\
\text { Units }\end{array}$ & $\begin{array}{r}\text { Percentage } \\
\text { of } \\
\text { Hispanic } \\
\text { officers in } \\
\text { Specialty } \\
\text { Units }\end{array}$ & $\begin{array}{r}\text { Total } \\
\text { Number of } \\
\text { Hispanic } \\
\text { officers in } \\
\text { the } \\
\text { department }\end{array}$ & $\begin{array}{r}\text { Percentage } \\
\text { of Hispanic } \\
\text { officers in } \\
\text { the } \\
\text { department }\end{array}$ & $\begin{array}{r}\text { Index of } \\
\text { Hispanic } \\
\text { representation } \\
\text { within } \\
\text { Specialty } \\
\text { Units }\end{array}$ \\
\hline Chicago & 1,635 & 146 & $8.9 \%$ & 1,668 & $12.1 \%$ & 0.73 \\
\hline Houston & 699 & 115 & $16.4 \%$ & 957 & $17.6 \%$ & 0.93 \\
\hline Detroit & 1,622 & 40 & $2.4 \%$ & 129 & $3.1 \%$ & 0.77 \\
\hline Dallas & 459 & 51 & $11.1 \%$ & 382 & $13.3 \%$ & 0.83 \\
\hline $\begin{array}{l}\text { San } \\
\text { Antonio }\end{array}$ & 260 & 119 & $45.7 \%$ & 784 & $41.6 \%$ & 1.09 \\
\hline $\begin{array}{l}\text { New } \\
\text { Orleans }\end{array}$ & 154 & 0 & $0.0 \%$ & 32 & $1.9 \%$ & 0.00 \\
\hline Denver & 170 & 37 & $21.7 \%$ & 269 & $18.5 \%$ & 1.17 \\
\hline $\begin{array}{l}\text { Fort } \\
\text { Worth }\end{array}$ & 96 & 13 & $13.5 \%$ & 123 & $10.5 \%$ & 1.28 \\
\hline $\begin{array}{l}\text { Kansas } \\
\text { City }\end{array}$ & 403 & 6 & $1.4 \%$ & 46 & $3.6 \%$ & 0.38 \\
\hline $\begin{array}{l}\text { San } \\
\text { Diego }\end{array}$ & 212 & 24 & $11.3 \%$ & 325 & $15.7 \%$ & 0.71 \\
\hline Columbus & 140 & 0 & $0.0 \%$ & 0 & $0.0 \%$ & 0.00 \\
\hline Cincinnati & 289 & 0 & $0.0 \%$ & 0 & $0.0 \%$ & 0.00 \\
\hline Miami & 374 & 204 & $54.5 \%$ & 596 & $53.3 \%$ & 1.02 \\
\hline Nashville & 409 & 0 & $0.0 \%$ & 0 & $0.0 \%$ & 0.00 \\
\hline $\begin{array}{l}\text { Virginia } \\
\text { Beach }\end{array}$ & 45 & 1 & $2.2 \%$ & 12 & $1.6 \%$ & 1.37 \\
\hline St. Louis & 545 & 4 & $73.0 \%$ & 17 & $1.0 \%$ & 0.73 \\
\hline $\begin{array}{l}\text { Long } \\
\text { Beach }\end{array}$ & 153 & 24 & $15.6 \%$ & 154 & $18.0 \%$ & 0.86 \\
\hline El Paso & 127 & 73 & $57.4 \%$ & 726 & $70.8 \%$ & 0.81 \\
\hline
\end{tabular}

TABLE 8: Index of Hispanic representation in police specialty units.

Note:

Data were obtained through a questionnaire mailed to the office of the Chief of Police or the office of the municipal Director of personnel (or equivalent) in the 50 largest cities in the United States. Eighteen (18) cities or $36 \%$ returned completed questionnaires. The index of Hispanic representation is calculated by dividing the percent of Hispanic officers in police specialty units by the percent of Hispanic police officers in the police department. An index approaching 1.0 indicates that a police department and or city is closer to achieving a representation of Hispanic police officers assigned to elite specialty units equal to their proportion in the police department. The Hispanic population of a city is derived from the 1990 census of the population. 


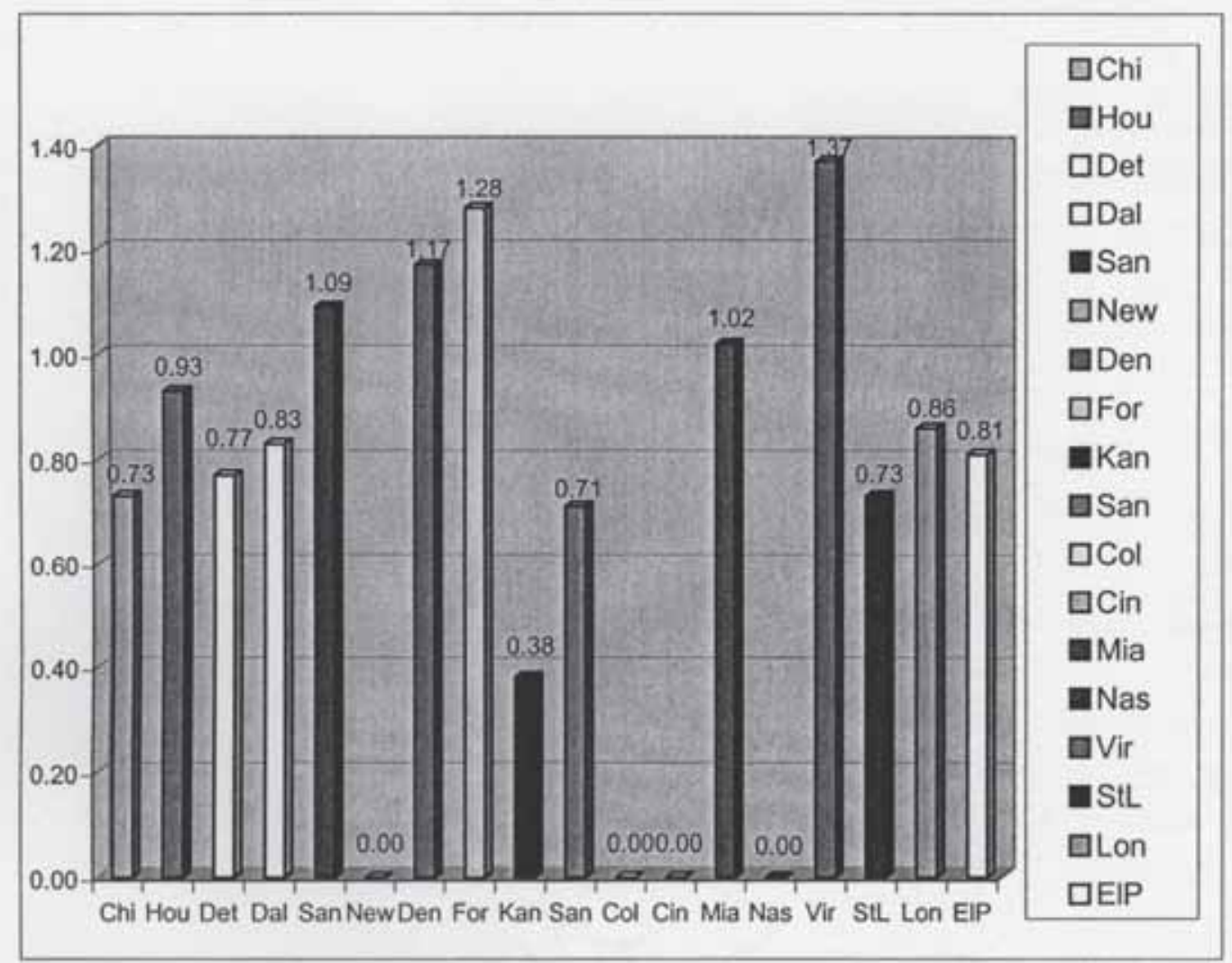

FIGURE 9: Index of Hispanic representation in police specialty units.

Note:

Data were obtained through a questionnaire mailed to the office of the Chief of Police or the office of the municipal Director of personnel (or equivalent) in the 50 largest cities in the United States. Eighteen (18) cities or $36 \%$ returned completed questionnaires. The index of Hispanic representation is calculated by dividing the percent of Hispanic officers in police specialty units by the percent of Hispanic police officers in the police department. An index approaching 1.0 indicates that a police department and or city is closer to achieving a representation of Hispanic police officers assigned to elite specialty units equal to their proportion in the police department. The Hispanic population of a city is derived from the 1990 census of the population. 


\begin{tabular}{|c|c|c|c|c|c|}
\hline City & $\begin{array}{r}\text { Total } \\
\text { Number of } \\
\text { Officers in } \\
\text { Specialty } \\
\text { Units }\end{array}$ & $\begin{array}{r}\text { Total } \\
\text { Number of } \\
\text { Hispanic } \\
\text { officers in } \\
\text { Specialty } \\
\text { Units } \\
\end{array}$ & $\begin{array}{r}\text { Percentage } \\
\text { of Hispanic } \\
\text { officers in } \\
\text { Specialty } \\
\text { Units }\end{array}$ & $\begin{array}{r}\text { Percentage of } \\
\text { Hispanic in } \\
\text { the } \\
\text { population }\end{array}$ & $\begin{array}{r}\text { Index of Hispanic } \\
\text { representation } \\
\text { within Specialty } \\
\text { Units }\end{array}$ \\
\hline Chicago & 1,635 & 146 & $8.9 \%$ & $8.1 \%$ & 1.09 \\
\hline Houston & 699 & 115 & $16.4 \%$ & $20.9 \%$ & 0.78 \\
\hline Detroit & 1,622 & 40 & $2.4 \%$ & $1.3 \%$ & 1.84 \\
\hline Dallas & 459 & 51 & $11.1 \%$ & $8.4 \%$ & 1.32 \\
\hline $\begin{array}{l}\text { San } \\
\text { Antonio }\end{array}$ & 260 & 119 & $45.7 \%$ & $36.5 \%$ & 1.25 \\
\hline $\begin{array}{l}\text { New } \\
\text { Orleans }\end{array}$ & 154 & 0 & $0.0 \%$ & $2.5 \%$ & 0 \\
\hline Denver & 170 & 37 & $21.7 \%$ & $11.7 \%$ & 1.85 \\
\hline Fort Worth & 96 & 13 & $13.5 \%$ & $7.8 \%$ & 1.73 \\
\hline $\begin{array}{l}\text { Kansas } \\
\text { City }\end{array}$ & 403 & 6 & $1.4 \%$ & $2.0 \%$ & 0.7 \\
\hline San Diego & 212 & 24 & $11.3 \%$ & $9.7 \%$ & 1.16 \\
\hline Columbus & 140 & 0 & $0.0 \%$ & $78.0 \%$ & 0 \\
\hline Cincinnati & 289 & 0 & $0.0 \%$ & $51.0 \%$ & 0 \\
\hline Miami & 374 & 204 & $54.5 \%$ & $56.3 \%$ & 0.96 \\
\hline Nashville & 409 & 0 & $0.0 \%$ & $69.0 \%$ & 0 \\
\hline $\begin{array}{l}\text { Virginia } \\
\text { Beach }\end{array}$ & 45 & 1 & $2.2 \%$ & $2.2 \%$ & 1 \\
\hline St. Louis & 545 & 4 & $73.0 \%$ & $98.0 \%$ & 0.74 \\
\hline $\begin{array}{l}\text { Long } \\
\text { Beach }\end{array}$ & 153 & 24 & $15.6 \%$ & $10.1 \%$ & 1.54 \\
\hline El Paso & 127 & 73 & $57.4 \%$ & $51.8 \%$ & 1.12 \\
\hline
\end{tabular}

TABLE 9: Index of Hispanic representation in police specialty units calculated with the local population.

Note:

Data were obtained through a questionnaire mailed to the office of the Chief of Police or the office of the municipal Director of personnel (or equivalent) in the 50 largest cities in the United States. Eighteen (18) cities or $36 \%$ returned completed questionnaires. The index of Hispanic representation is calculated by dividing the percent of Hispanic officers in elite police specialty units by the percent of Hispanics in the local population. An index approaching 1.0 indicates that a police department and or city is closer to achieving a representation of Hispanic police officers assigned to elite specialty units equal to their proportion in the local population. The Hispanic population of a city is derived from the 1990 census of the population. 


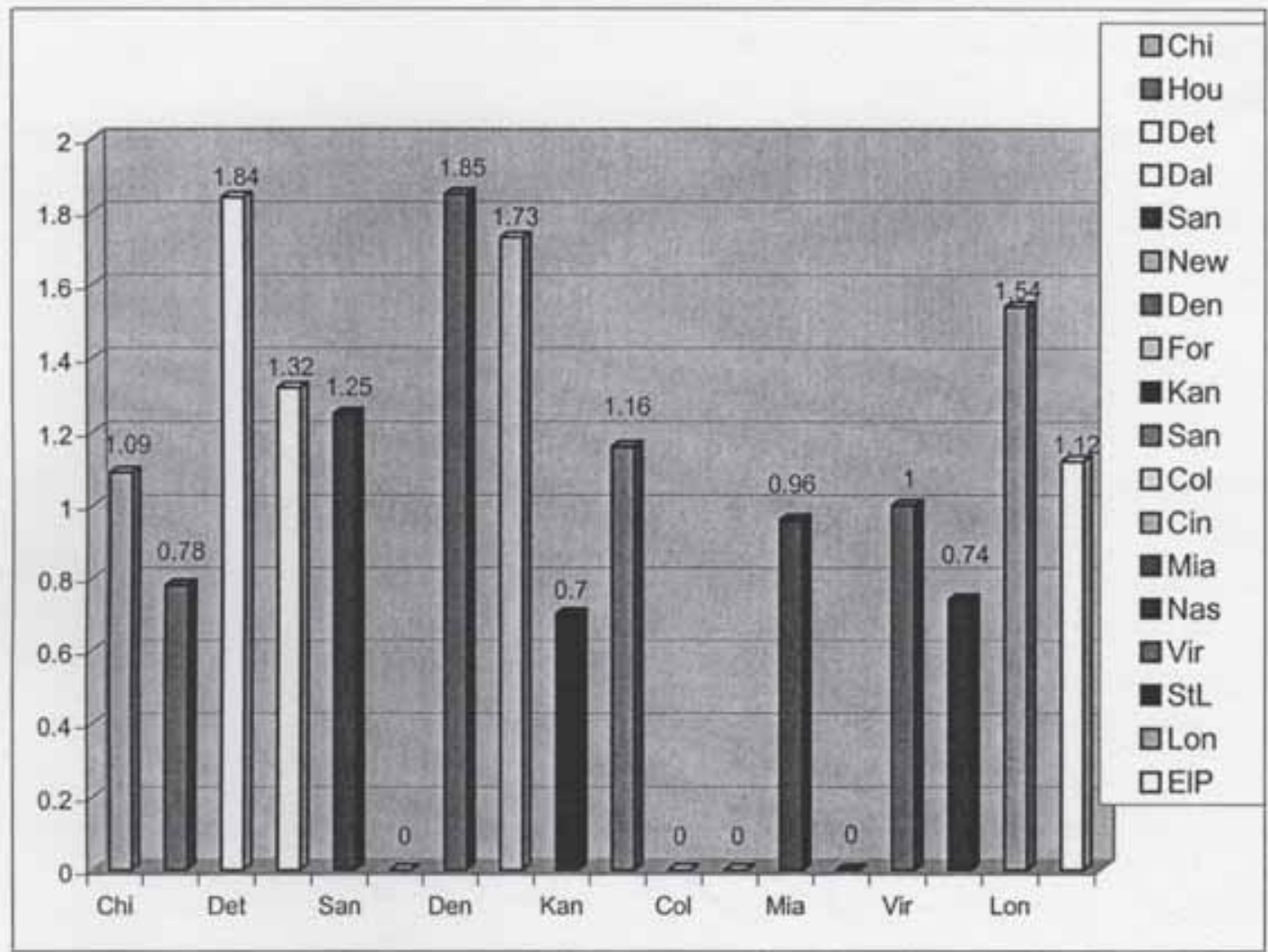

FIGURE 10: Index of Hispanic representation in police specialty units calculated with the local population.

Note:

Data were obtained through a questionnaire mailed to the office of the Chief of Police or the office of the municipal Director of personnel (or equivalent) in the 50 largest cities in the United States. Eighteen (18) cities or $36 \%$ returned completed questionnaires. The index of Hispanic representation is calculated by dividing the percent of Hispanic officers in elite police specialty units by the percent of Hispanics in the local population. An index approaching 1.0 indicates that a police department and or city is closer to achieving a representation of Hispanic police officers assigned to elite specialty units equal to their proportion in the local population. The Hispanic population of a city is derived from the 1990 census of the population. 


\section{THE RACIAL REPRESENTATION OF THE POLICE DEPARTMENTS:}

Figure 11 examines the distribution of police departments which had a disproportionate under-representation index below $(1,00)$ of black, white, and Hispanic police officers when calculated with the local population. Of the 18 police departments in the study, black police officers had the highest number 15 or (83.3\%) of police departments with an index below (1.00). Hispanic police officers followed with 7 or $(38.8 \%)$. White police officers had the lowest number of police departments 1 or $(5.5 \%)$ with an index below (1.00).

Figure12 examines the distribution of police departments that had a disproportionate under-representation index below (1.00) of black, white, and Hispanic police officers in elite police specialty units, when calculated with the local population. Of the three racial groups of police officers, black police officers had the highest number 15 or $(83.3 \%)$ of police departments with an index below (1.00). Hispanic police officers followed with 7 or $(38.8 \%)$. White police officers had the lowest number at 1 or $(5.5 \%)$.

Figure 13 displays the distribution of police departments which a had representation index less than (1.00) for black, white, and Hispanic police officers in elite police specialty units when calculated with police officers assigned to general patrol duties. Of the 18 police departments used in the study, 6 or $(33.3 \%)$ had an index than (1.00) for white officers. 10 or $(55.5 \%)$ of the police departments had an index less than (1.00) for black officers. Lastly, 5 or (33.3\%) 
of the police departments had an index less than (1.00) for Hispanic officers. Note: in figure 13 three police departments were not used in the index calculation for Hispanic police officers, due to the lack of Hispanic representation within the police departments..

Figure 14 illustrates the indexes of white, black and Hispanic police officer's representation within the 18 police departments used in this study and the local population. white police officers $=$ to 1.31 , black police officers $=$ to .72 , and Hispanic police officers are $=$ to 1.12 .

Figure 15 illustrates the indexes of white, black, and Hispanic police officer's representation within the 18 police department's elite police specialty units and the employees of the police departments not assigned to the elite police specialty units. The indexes are as follows: white police officers $=1.11$, black police officers $=$ 1.04 , and Hispanic police officers $=.70$.

Figure 16 illustrates the indexes of white, black, and Hispanic police officer's representation within 18 police departments used in the study, and the local population. The indexes are as follows: white police officers $=1.36$, black police officers $=.78$, and Hispanic police officers $=.94$. 


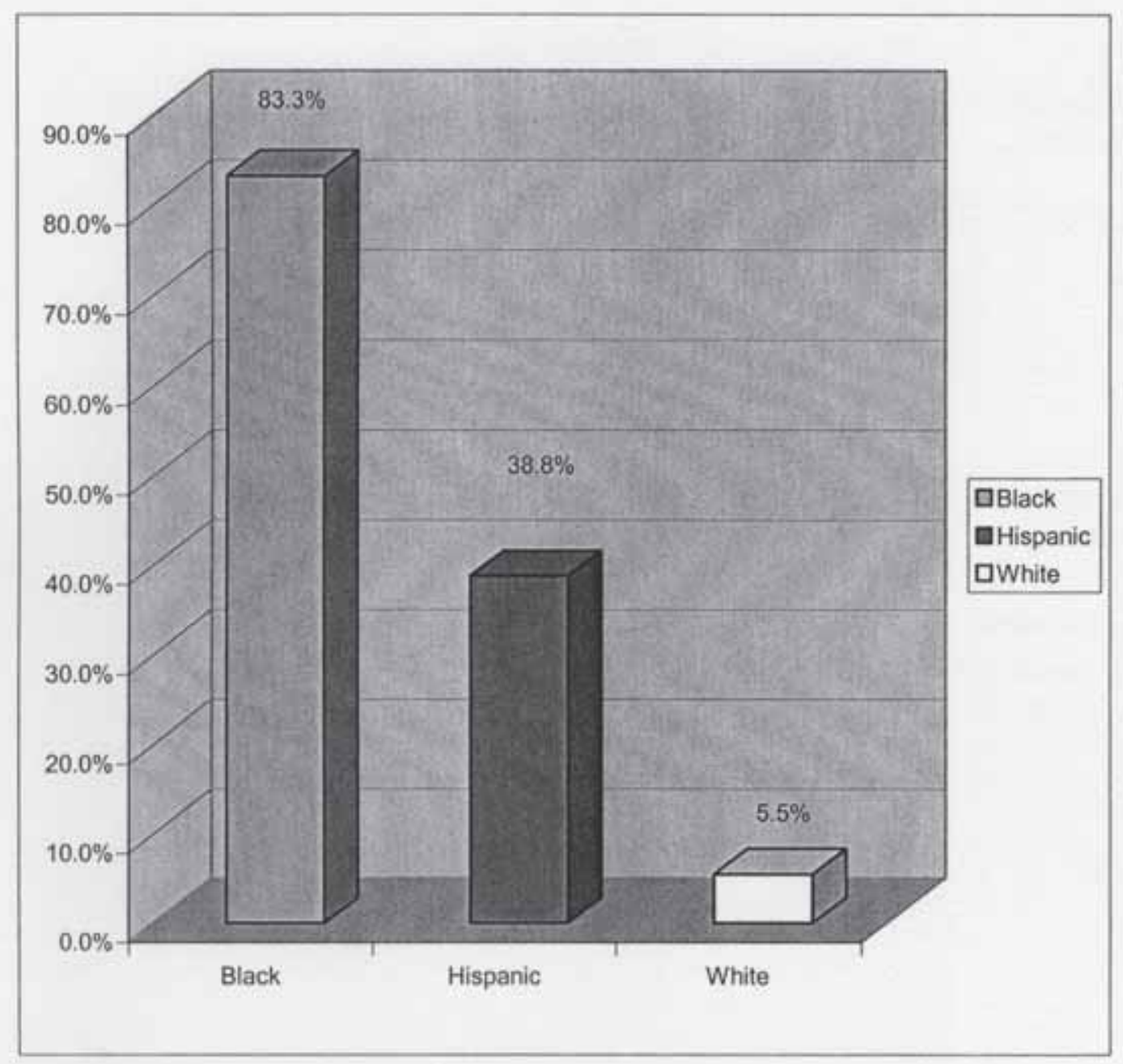

FIGURE 11: Police departments with a disproportionate (under-Representation) of police officers by race compared to the local population 


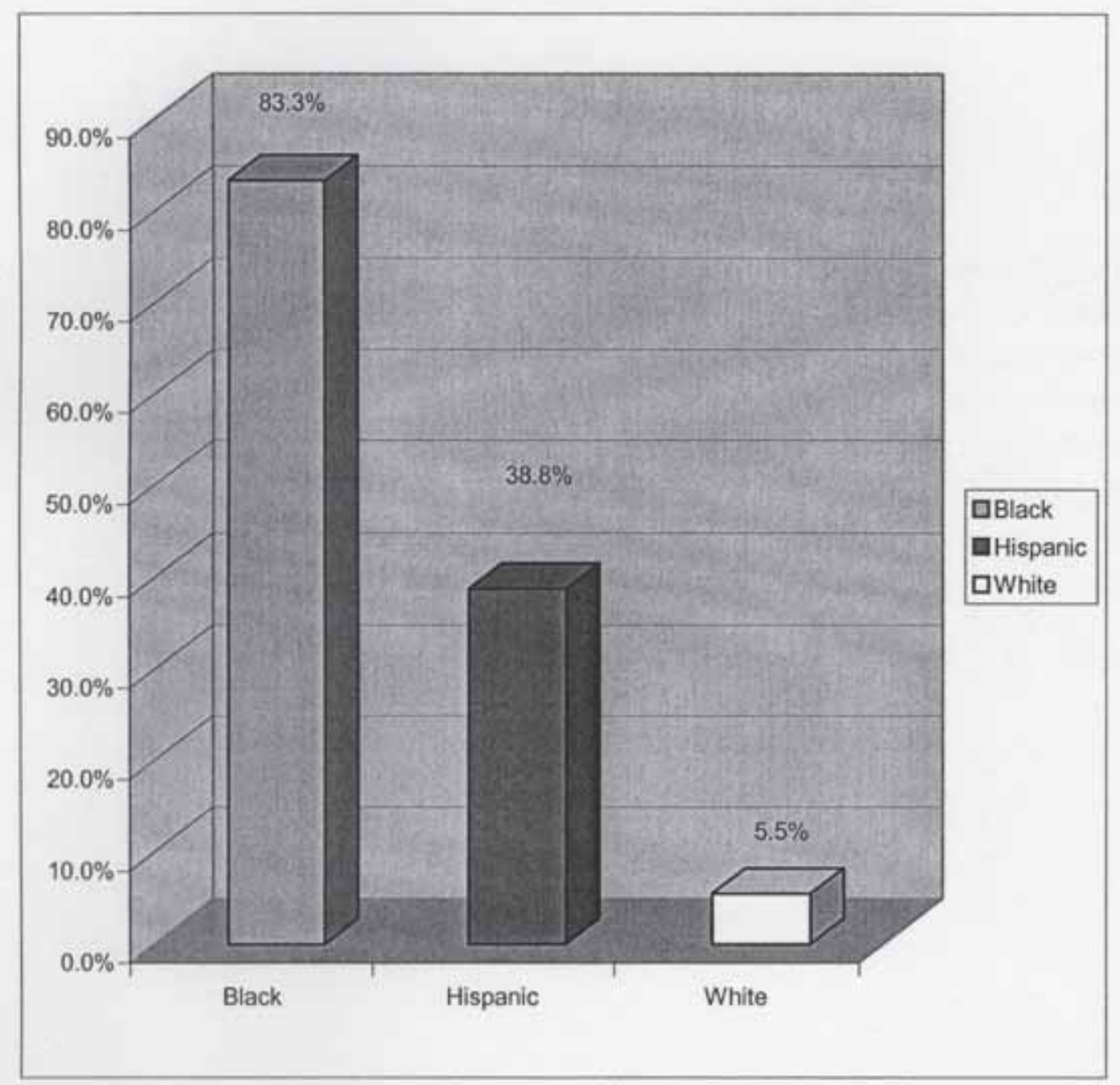

FIGURE 12: Departments with police specialty units having a disproportionate (underRepresentation) of police officers by race compared to the local population 


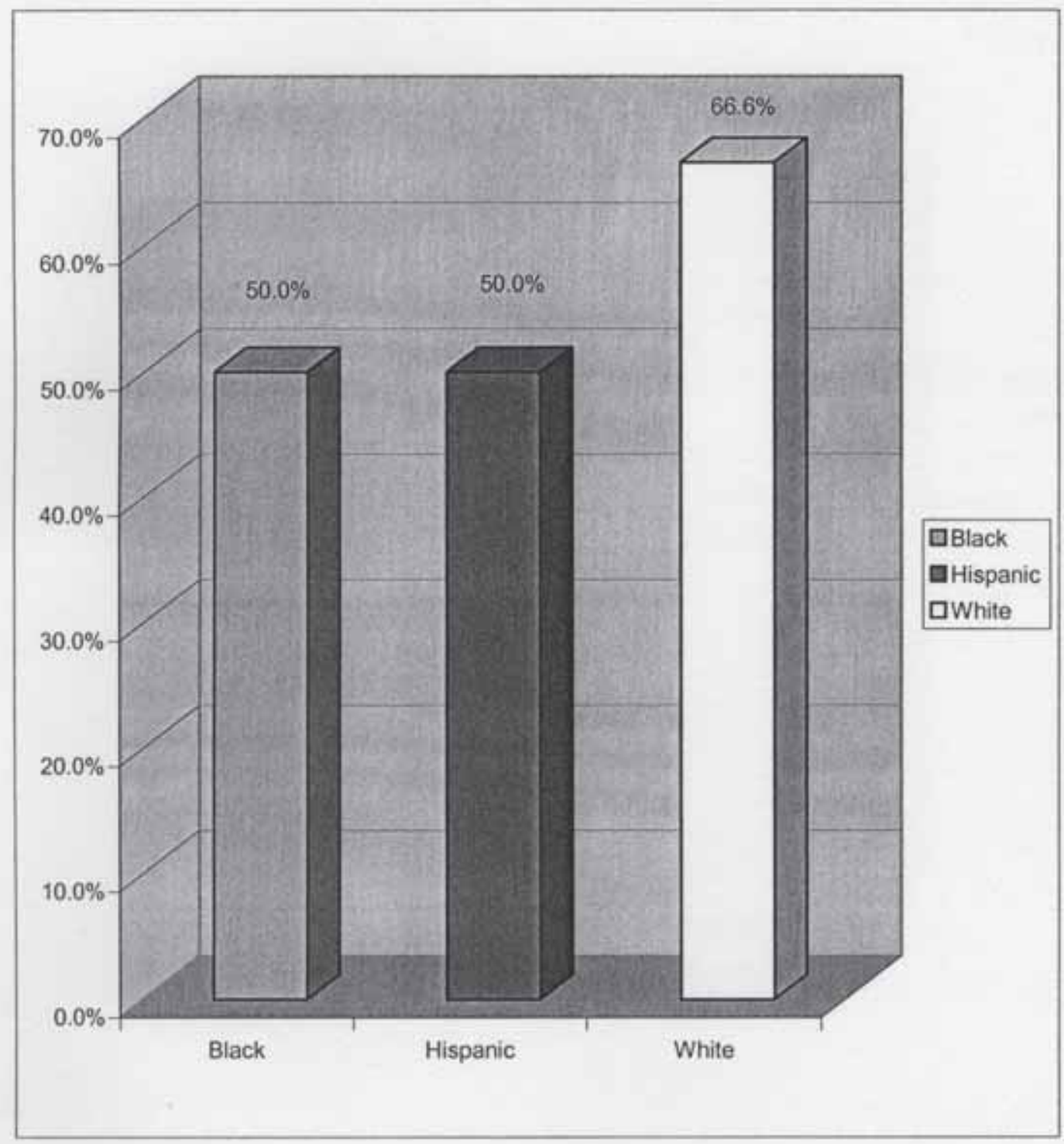

FIGURE 13: Departments with police specialty units having a disproportionate (underRepresentation) of police officers by race compared to police officers in the department 


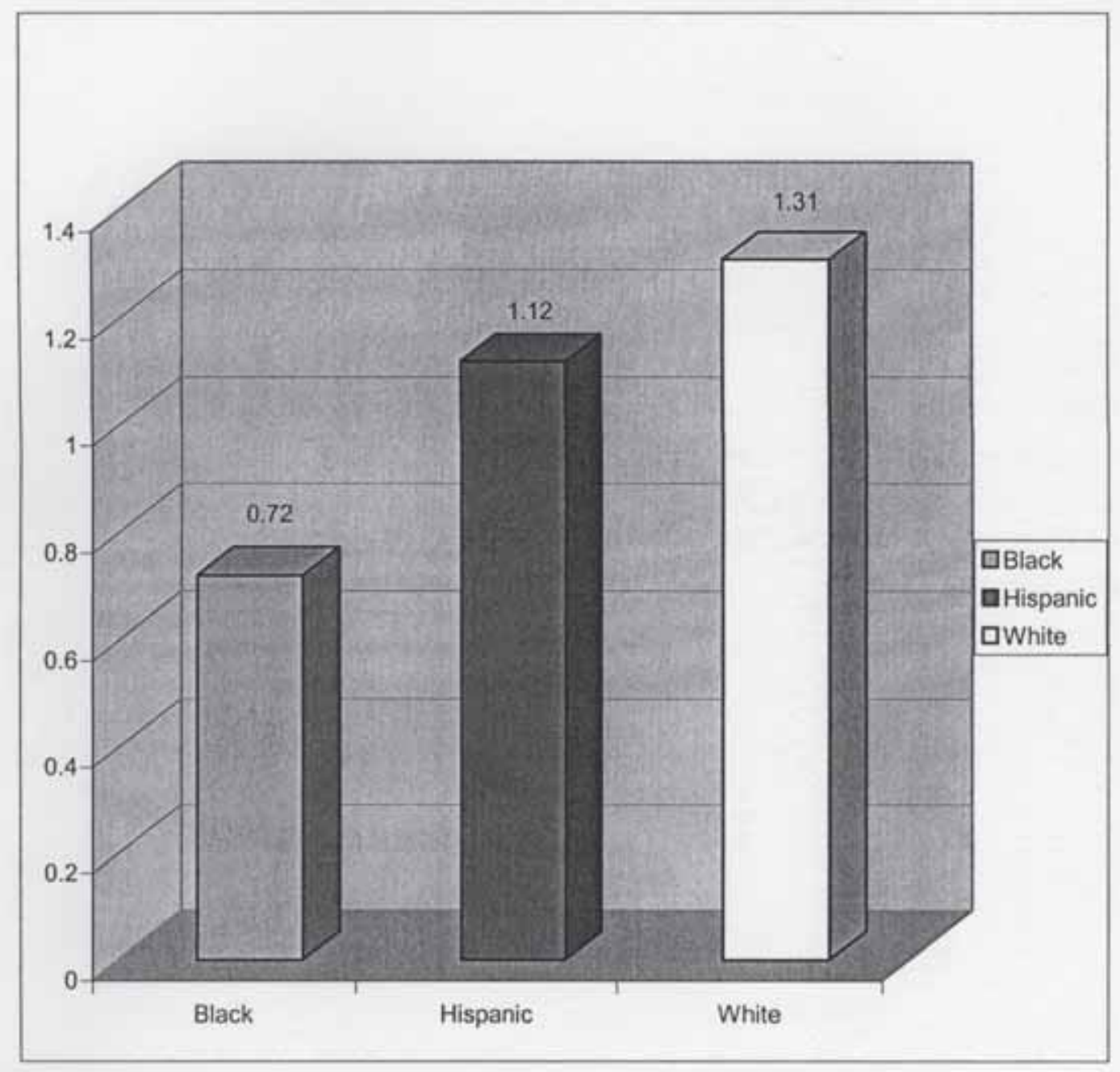

FIGURE 14: Police officers race representation by index: Department compared to race representation in the local population 


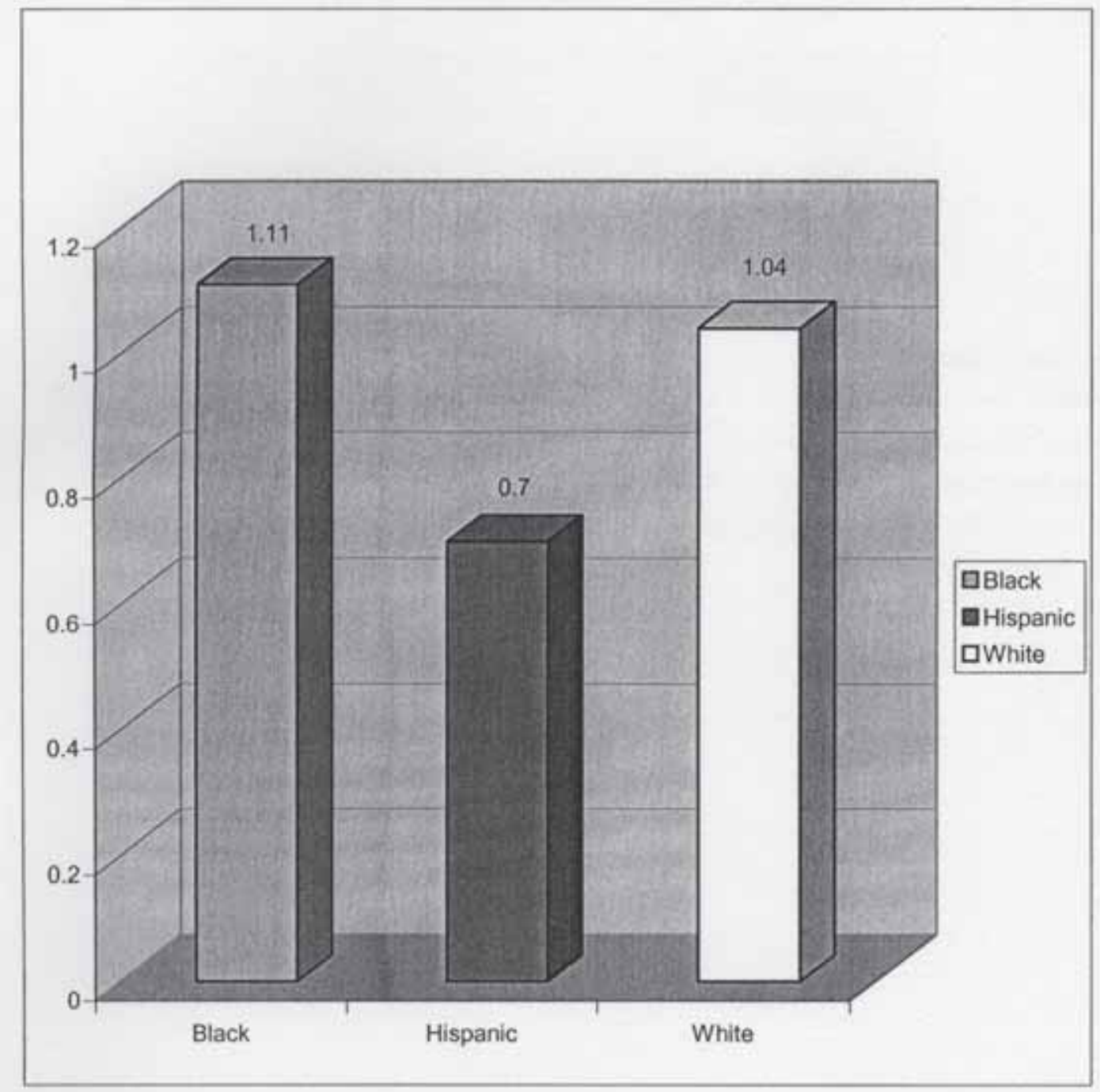

FIGURE 15: Police officers race representation by index: Police specialty units compared to race representation in the department 


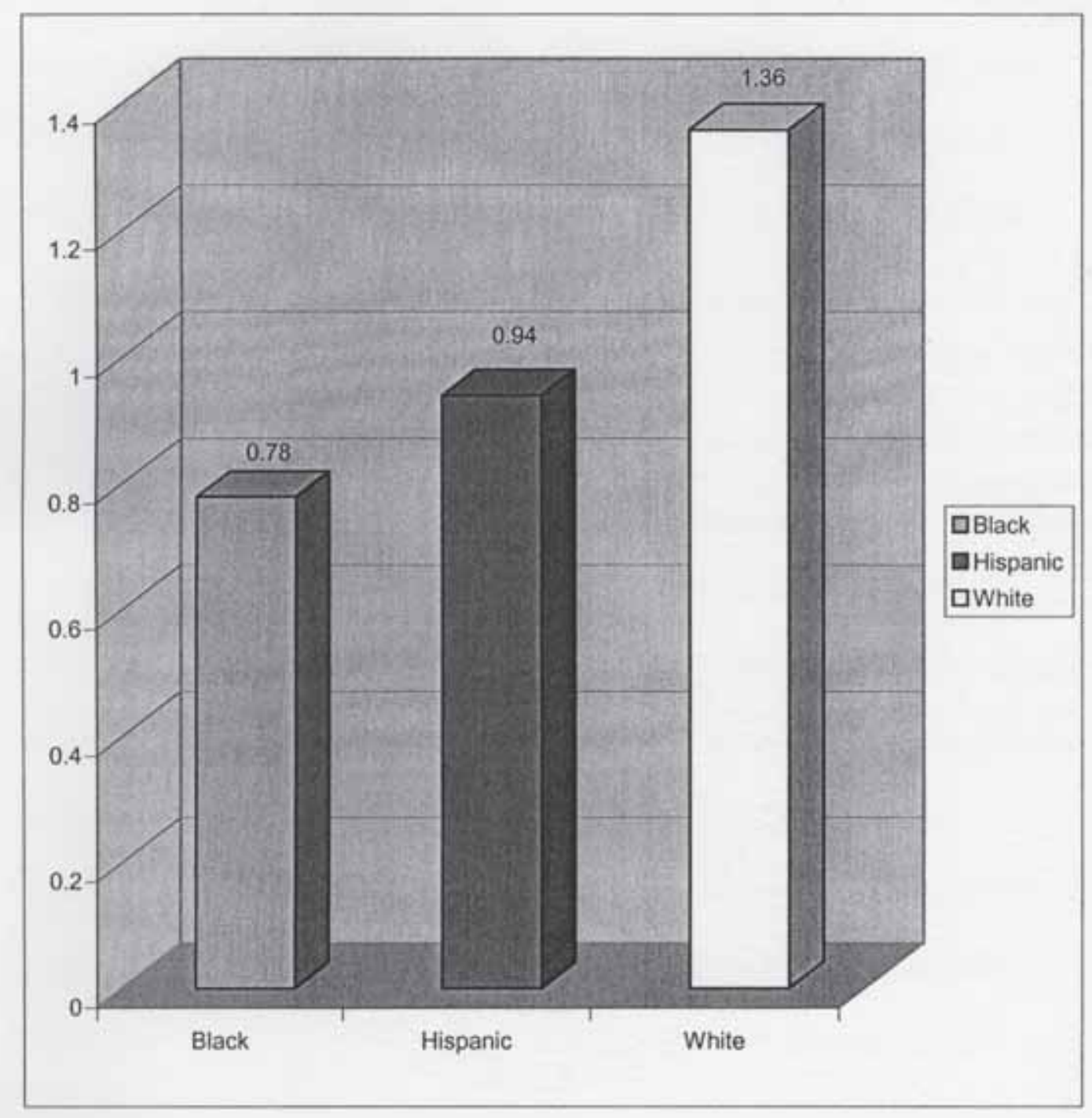

FIGURE 16: Police officers race representation by index: Police specialty units compared to race representation in the local population 


\section{THE CHIEF OF POLICE FACTOR:}

The18 police departments used in this study, all have a chief of police that is responsible for the daily operational procedures and management of their police department. The racial demographics of the chiefs of police are as follows: 9 or $50 \%$ of the chiefs of police are white, 7 or $38.8 \%$ are black, and 2 or $11.1 \%$ are Hispanic.

\section{WHITE CHIEFS OF POLICE:}

The data for white chiefs of police indicated the following: 9 or $100 \%$ of the white chiefs of police had an over-representation of white police officers employed at their police departments compared to whites within the local population. Moreover, 6 or $66.6 \%$ of the police departments with white chiefs of police had an over-representation of white police officers assigned to elite police specialty units, compared to the number of white police officers employed at the police department, and not assigned to an elite police specialty unit. Lastly, 7 or $88.8 \%$ of the police departments with white chiefs of police had an over-representation of white police officers assigned to elite police specialty units, compared to the percentage of whites in the local population.

The data indicated that 7 or $77.7 \%$ of the police departments with white chiefs of police had an under-representation of black police officers employed at the police departments and assigned to elite police specialty units disproportionate to the percentage of blacks within the local population. 
Furthermore, 6 or $66.6 \%$ of the police departments with white chiefs of police had an under-representation of black police officers assigned to elite police specialty units, disproportionate to the percentage of black police officers employed at the police departments.

The data for police departments with white chiefs of police indicated that 3 or $33.3 \%$ of the police departments had an under-representation of Hispanic police officers disproportionate to the percentage of Hispanic police officers employed at the police departments, and Hispanics within the local population. Lastly, the data indicated that Hispanic police officers were under-represented in 4 or $44.4 \%$ of the police department's elite police specialty units, disproportionate to the Hispanic representation within the police department.

\section{BLACK CHIEFS OF POLICE}

The data for black chiefs of police indicated the following: 1 or $14.2 \%$ of the police departments with a black chief of police had an over-representation of black police officers employed at the police department compared to the percentage of blacks within the local population.

The data indicated that 7 or $100 \%$ of the police departments that employed a black chief of police had an under-representation of black police officers assigned to elite police specialty units, disproportionate to the percentage of blacks within 
the local population.

Moreover, the data implied that 5 or $71.4 \%$ of the police departments with a black chief of police had an over-representation of black police officers assigned to elite police specialty units, compared to the percentage of black police officers within the police department and not assigned to an elite police specialty unit.

The data indicated that of the police departments that employed a black chief of police, 7 or $100 \%$ of the police departments had an over-representation of white police officers within the police department and assigned to elite police specialty units compared to the percentage of whites within the local population. Furthermore, the data implied that 4 or $57.1 \%$ of the police departments with a black police chief had an over-representation of white police officers assigned to elite police specialty units when compared to the percentage of white police officers within the department and not assigned to an elite police specialty unit. The data indicated that of the police departments with a black chief of police, 4 or $57.1 \%$ of the police departments had an under-representation of Hispanic police officers employed within the police department and assigned to elite police specialty units, compared to the percentage of Hispanics within the local population. Lastly, 5 or $100 \%$ of the police departments with a black chief of police, had an under-representation of Hispanic police officers assigned to elite police specialty units, disproportionate to the percentage of Hispanic police officers employed by the police department as sworn officers. Note: 2 of the police 
departments with black chiefs of police were not utilized in the aforementioned calculation, due to the lack of Hispanic police officer's representation within the police departments.

\section{HISPANIC CHIEFS OF POLICE:}

The data indicated that of the police departments that employed a Hispanic chief of police, 1 or $50 \%$ of the police departments had an over-representation of white police officers employed within the department and assigned to elite police specialty units, compared to the percentage of whites within the local population. Moreover, 2 or $100 \%$ of the police departments that employed a Hispanic police chief, had an over-representation of white police officers assigned to elite police specialty units, compared to the percentage of white police officers employed by the police department, and not assigned to an elite police specialty unit.

The data for the police departments that employed a Hispanic police chief, indicated that 1 or $50 \%$ of the police departments had an over-representation of black police officers assigned to elite police specialty units when compared to the percentage of blacks within the local population. The data also implied that 1 or $50 \%$ of the police departments that had a Hispanic police chief, had an overrepresentation of black police officers assigned to elite police specialty units when compared to the percentage of black police officers within the police department, and not assigned to an elite police specialty unit. 
The data also indicated that 2 or $100 \%$ of the police departments that had a Hispanic police chief, had an over-representation of Hispanic police officers employed by the department as sworn police officers and assigned to elite police specialty units when compared to the percentage of Hispanics within the local population.

TABLE 10

white police chiefs

white police officers: 65.3

black police officers: 14.4

Hispanic police officers: 17.5

\section{black police chiefs}

white police officers: 48.7

black police officers: 33.5

Hispanic police officers: 5.1
Hispanic police chiefs

white police officers: 47.5

black police officers: 6.0

Hispanic police officers: 44.6

Average percent of police officers by race, employed at police departments with white, black, and Hispanic police chiefs.

\section{Table 11}

white police chiefs

white police officers: 68.1

black police officers: 13.6

Hispanic police officers:17.2 black police chiefs

white police officers: 61.9

black police officers: 33.3

Hispanic policer officers: 4.06
Hispanic police chiefs

white police officers: 53.9

black police officers: 6.7

Hispanic police officers: 39.5

Table 11 illustrates the average percentage of police officers by race assigned to elite police specialty units within the 18 police departments used in this study.

The data in tables 10 and 11 indicates that the representation percentage of police officers who are of the same race as the chief of police, is increased among the police officers employed within the police departments, and assigned to elite 
police specialty units within the police departments. The data implies that the aforementioned concept is consistent for white, black, and Hispanic police officers.

The data implies that police chiefs who hold the highest position of authority within a given police department, have the ability use their authority, discretion, and power to influence the selection process of new police officers hired in the police department and increase the number of police of the same race as the chief of police who are to selected as members of elite police specialty units.

The increased representation numbers of police officers who are of the same race as the chief of police within a police department, and selected as members of elite police specialty units, is viewed in the law enforcement community as " taking care of your own". For the most part, this procedure is tolerated by other police officers who are not of the same race as the police chief. However, as the research suggests, when police officers not of the same race as the chief of police perceive that their representation within the police department, promotional advancement, and membership in elite police specialty units is decreasing or not improving at a satisfactory rate, resentment, envy, and law suits alleging racial bias, discrimination, reverse discrimination, and disparate treatment begin to emerge. 


\section{CHAPTER 6}

\section{DISCRIMINATION LAWSUITS:}

As the research indicated, 5 or $27.7 \%$ of the police departments used in this study have had law suits filed against the organization alleging racial bias, discrimination, or reverse discrimination, by police officers within the police department. ( Black Police In America. 1996 ).

In 1974, given the sordid history of racial discrimination in the city of Detroit's police department, in which $19 \%$ of the police force was black, in a city where the majority of the local population was black, the mayor of Detroit who was black, implemented an affirmative action plan in which the police department promoted a black officer for every white officer that was promoted. In effect, this was a quota system of promoting officers.

This system of promoting encountered several problems. Just as in other cities, white police officers resisted the affirmative action plan to promote black and white police officers on a quota basis. In 1977, the Detroit Police Officers Association (DPOA) filed a lawsuit to block the plan and force the city to promote police officers strictly on the basis of "merit" and seniority, rather than by quota. (Black Police In America. p99.1996).

The city of Houston police department had a long history of discriminating against and limiting the promotional opportunities of black police officers. Blacks of the force remained second-class officers assigned exclusively to Houston's black 
communities. In the 110 years that blacks had served on Houston's police force, only one black police officer had ever achieved a promotion above sergeant, which occurred in 1982, just prior to the hiring of Houston's first black chief of police, who was

selected for the purpose of reforming the police department. (Black Police In America. p. 93. 1996)

In the city of Atlanta's police department, in 1973 when the chief of police who was black, hired and promoted more black police officers in an attempt to integrate a police department that was predominantly white, white police officers charged the police chief with "reverse discrimination". The Atlanta FOP and PAA took over the racial discrimination suit that the A.A.P.L. had filed against the chief of police, claiming that the police department's black administrators were discriminating against whites. In 1976, the two organizations succeeded in obtaining an injunction which blocked all hiring and promotions in the Atlanta Police Department. (Black Police In America. p. 90.1996)

In the city of Columbus, Ohio, the first black police officer was promoted to the rank of police sergeant, after filing a lawsuit to force the Columbus police department to open the rank of sergeant to blacks. (Blacks Police In America. p. 82. 1996)

In 1975, the St. Louis Police Officer Association publicly condemned the promotion of black police officers as "reverse discrimination," detrimental to department morale. One year later, the POA unsuccessfully petitioned for an 
injunction to block promotions made by the police board. (Black Police In America. p98. 1996)

In 1967, Newark's predominantly white police force had expressed its resentment toward the appointment of the department's first black police captain, because they felt that he received his appointment only because of his race.(Black Police In America. p.85. 1996).

In the South, Miami's MCPBA filed one of the earliest lawsuits charging a police department with racial discrimination in hiring and promotion. Members of the MCPBA requested compensation for the department's failure to provide them police training and for the many years that the department had regulated them to a separate facility. (Black Police In America. p.78. 1996)

A white police officer accused in the beating of a black undercover officer who was mistaken for a murder suspect was fired in connection with the beating which occurred in 1995. The black police officer was working undercover in the city's Roxbury neighborhood when he was allegedly mistaken for a murder suspect during a foot chase and beaten severely by several white officers. The black police officer suffered a concussion, egg-sized contusions on his head, multiple facial cuts and kidney damage and spent the next six months out of work. The city of Boston agreed to pay nearly 1.3 million dollars to the black police officer to settle a civil rights lawsuit against the city and the police department. (Boston Cop Fired in Police Beating. Associated Press 1.1999)

A federal judge refused to throw out a lawsuit against New York City alleging 
that a police department specialty unit unlawfully stops and frisks young black and Latino men based on their skin color. The street crimes unit is an elite squad of police officers whose goal is to reduce violent crime and remove illegal firearms from the streets. The unit came under intense scrutiny after killing an unarmed black immigrant who died in a hail of 41 bullets as he stood in his apartment building. (Judge refuses to dismiss race suit against NYC.Reuters Limited.

Bedlam breaks out in Louisville, Kentucky after the Louisville police department's chief of police is fired after awarding medals of valor to two police officers who shot and killed a black man who tried to run down the officers in a stolen car. (American Police Beat p.54 2000)

If teachers and trainers are role models, then the Oregon Police Academy is a breeding ground for racists. Recently, officials at the state's academy in Monmouth, Oregon admitted that three senior officers, all instructors, ridiculed and harassed a student because he was Jewish. The harassment included sarcastic remarks about circumcision, eating pork, and drugged-out Jews saluting Adolf Hitler and admiring his mustache. (Minorities and the law: Police academy breeds racism. The Rap Sheet: p 54. 1997)

Lawmakers try to get out of a decree that aimed to increase the number of black police officers. The Fayetteville, NC, city council's fight over the police department will not stop plans to free the city from a 1974 court order that calls for 
a fixed percentage of black police officers to be hired and promoted. The order, a consent decree filed in US District Court, in response to a complaint made by black police officers, directed the Fayetteville police department to increase hiring and promotion of blacks until they (blacks) made up at least $30 \%$ of the total police force and $30 \%$ of the captains and lieutenants. (Fayetteville Observer-Times 1997) The Illinois State Police have been caught practicing "reverse discrimination" under the guise of affirmative action. A US District Judge ruled that as many as 5000 non-minority officers and officer-applicants were illegally denied either promotions within the State Police, or the opportunity for a job with the State Police. (Illinois State Police guilty of reverse discrimination: Adversity. Net. 1999) 16 non-minority deputies in Georgia's Futon County Marshall's department were forced to sue this Georgia police department for reverse discrimination. The court found that the sheriff who is a black female, and the Futon County, Georgia Sheriff's department were guilty of practicing "reverse discrimination" and "antiwhite diversity" policies in this Georgia police department. The court found that the sheriff's policies systematically excluded qualified "non-minority" employees of the department from advancement solely for racial reasons. (Black Female Sheriff Hires Her Own: Adversity. Net. 1996)

In Danbury, Connecticut, the city's retired and current black police officers are taking the city to court, claiming that officials violated a 1994 federal court settlement ordering the Danbury police department to hire more black police officers. (The News-Times: p1.1997) 
In 1994, almost 200 black and Hispanic police officers in the city of Chicago's police department filed a federal lawsuit contesting a controversial sergeants exam that the plaintiffs maintain will turn back the clock to the discrimination of 1973. (Jet .Oct. p.19. 1994)

"Race will be the problem of the 20th century," said W.E.B. DuBois almost 90 years ago. As the research indicates, discrimination and nepotism continue to exist in law enforcement. The data indicates that in recent years, blacks have obtained political power within large metropolitan cites and achieved high level managerial positions in police departments across the United States. However, black police officers continue to be an under-represented minority within law enforcement. and subjected to discrimination.

\section{BLACK POLICE PERSONALITIES:}

The constant struggle of the black police officer to prove himself and his ability as a police officer, in order to gain equality, respect, and the confidence of his peers and supervisors, is a taxing drain on the officer physically, emotionally, and psychologically. This in turn, can cause the black police officer who is trying to advance to the status of becoming a member of an elite specialty unit to work harder and appear to be increasingly more dedicated than his peers. As the research 
suggests, this type of work ethic can cause resentment, envy, and jealously, thereby causing the officer to be black-balled and excluded from advancing within the police department.

This relentless pursuit to proves one's self, in order to become a member of an elite police specialty unit, can have a destructive and devastating effect on the life and career of the black police officer. If he is unsuccessful in achieving his goal of becoming a member of an elite police specialty unit, and subsequently speaks out against and criticizes the establishment or the status quo, he is labeled a militant, quickly isolated and singled out for oppressive destructive attracts by his counterparts. He is then termed out of control and a renegade officer not having the team player concept, which is considered "the kiss of death" within the law enforcement community, thereby making him an undesirable and unwanted candidate for the elite police specialty units.

The data suggests that the personalities of black police officers assigned to elite police units can be categorized into four different personality types.

1. (The Sell-Out). An individual with the "sell-out" personality has completely discarded his racial identity and heritage in order to fit in with the majority. This individual exhibits selfish characteristics and only cares about himself and his upward mobility and advancement within the police department. This individual is concerned with how he is perceived by the majority, and continues to seek their approval and confidence. Individuals having the "sell-out" personality oftentimes 
betray and deceive other black police officers not having the "sell-out" personality in order to show and demonstrate their loyalty and allegiance to the majority, and move up the ladder of success within the police department.

2. (The Adaptive Assimilator) Having the personality of an "adaptive assimilator" allows an individual to have the ability to assume the values, ideologies, and beliefs of the dominate majority, and institute them as his own. A person having the "adaptive assimilator" personality, changes his beliefs, views, and opinions according to whichever group is dominant and in control. This personality type is noted for inconsistency and lack of direction. However, a person having the "adaptive assimilator" personality is tolerated and viewed as no threat to the majority or dominant group.

3. (The Non-Conformist) A person with this personality type maintains his own identity and heritage. This individual remains independent of the dominate group. A person with the "non-conformist" personality is primarily concerned with surviving and performing his job responsibilities at the highest level. This person is content with his job placement, and not concerned with moving up the ladder of success within the police department. A person with a "non-conformist" personality is tolerated by the majority or dominate group, because of their exceptional job performance and work production. However, persons having this type of personality are viewed by the majority or dominate group as a possible threat to the fundamental cohesiveness of the unit.

4. (The Rebellious Non-conformist) A person having this personality type is 
independent of the majority or dominate group. This individual challenges decisions that are perceived to be unfair or biased. A person having the "rebellious non-conformist" personality, oftentimes speaks out both publicly and privately against racial and discriminatory injustices. This individual maintains a relentless pursuit of obtaining racial equality and fairness with the majority or dominate group. A person with this personality type is primarily concerned with fair treatment and equal opportunity for success and advancement for members of his own race, and less concerned with the stigma attached to him, or the consequences that may be directed toward him by members of the dominate group. It is this personality type that is viewed by members of the dominate group, as a constant threat to the status quo and considered the most dangerous.

It is the "non-conformist and rebellious non-conformist" personalities that many black police officers fit into, and can identify with. There are also many black police officers that fit in and can identify with the "sell-out and adaptive assimilator" personalities. It is those police officers who fit into the "sell-out and adaptive assimilator" personalities that the dominate group are more comfortable with, and are subsequently selected as members of elite police specialty units more often than police officers that have "non-conformist or rebellious non-conformist" personalities.

It is perceived that police officers with "non-conformist and rebellious nonconformist " personalities threaten the status quo of the police special unit, thereby 
making these police officers less likely to be considered as desirable applicants in the selection process for members of elite police specialty units.

Lastly, police officers having "non-conformist and rebellious non-conformist" personalities, do oftentimes manage to become members of elite police specialty units by over-coming the internal barriers which had previously excluded them from elite police specialty units. This is achieved through lawsuits, persistent application and highly publicized occupational related accomplishments as police officers. Also, through the intervention of friends, anonymous sources, or a compassionate interested person sharing the same beliefs as the police officer, in a position

of power having the decision making authority to assign police officers to elite police specialty units.

\section{T-TEST CONCLUSIONS}

\section{BLACKS}

TABLE 12

\begin{tabular}{|c|c|c|c|c|c|c|}
\hline & Mean & $\mathrm{N}$ & Std. Dev & $\begin{array}{c}\text { Std. Error } \\
\text { Mean }\end{array}$ & T-test sig. & \begin{tabular}{|c} 
Representat- \\
ion
\end{tabular} \\
\hline Equality & 1.0000 & 18 & .0000 & .0000 & \multirow[t]{2}{*}{.000} & \multirow[t]{2}{*}{ UNDER } \\
\hline $\begin{array}{l}\text { Black department } \\
\text { representation }\end{array}$ & .7233 & 18 & .1845 & $4.349 \mathrm{E}-02$ & & \\
\hline & & & & & & \\
\hline Equality & 1.0000 & 18 & .0000 & .0000 & \multirow[t]{2}{*}{.349} & \multirow[t]{2}{*}{ EQUAL } \\
\hline $\begin{array}{l}\text { Black SU internal } \\
\text { representation }\end{array}$ & 1.1161 & 18 & .5110 & .1204 & & \\
\hline & & & & & & \\
\hline Equality & 1.0000 & 18 & .0000 & .0000 & \multirow[t]{2}{*}{.017} & \multirow[t]{2}{*}{ UNDER } \\
\hline $\begin{array}{l}\text { Black SU } \\
\text { representation }\end{array}$ & .7872 & 18 & .3416 & $8.050 E-02$ & & \\
\hline
\end{tabular}




\section{TABLE 13}

\section{WHITES}

Sample Statistics

\begin{tabular}{|c|c|c|c|c|c|c|}
\hline & Mean & $\mathrm{N}$ & \begin{tabular}{c|} 
Std. \\
Deviation
\end{tabular} & $\begin{array}{l}\text { Std. Error } \\
\text { Mean }\end{array}$ & T-test sig & $\begin{array}{c}\text { Representat- } \\
\text { ion }\end{array}$ \\
\hline Equality & 1.0000 & 18 & .0000 & .0000 & \multirow[t]{2}{*}{.000} & \multirow[t]{2}{*}{ OVER } \\
\hline $\begin{array}{l}\text { White } \\
\text { department } \\
\text { representation }\end{array}$ & 1.3144 & 18 & .1928 & $4.544 E-02$ & & \\
\hline & & & & & & \\
\hline Equality & 1.0000 & 18 & .0000 & .0000 & \multirow[t]{2}{*}{.000} & \multirow[t]{2}{*}{ OVER } \\
\hline $\begin{array}{l}\text { White SU } \\
\text { internal } \\
\text { representation }\end{array}$ & 1.3678 & 18 & .2317 & $5.462 \mathrm{E}-02$ & & \\
\hline & & & & & & \\
\hline Equality & 1.0000 & 18 & .0000 & .0000 & \multirow[t]{2}{*}{.000} & \multirow[t]{2}{*}{ OVER } \\
\hline $\begin{array}{l}\text { White SU } \\
\text { representation }\end{array}$ & 1.3678 & 18 & 2317 & $5.462 \mathrm{E}-02$ & & \\
\hline
\end{tabular}

TABLE 14

\section{HISPANICS}

Sample Statistics

\begin{tabular}{|c|c|c|c|c|c|c|}
\hline & Mean & $\mathrm{N}$ & Std. Deviation & $\begin{array}{l}\text { Std. Error } \\
\text { Mean }\end{array}$ & $\begin{array}{l}\text { T-test } \\
\text { sig. }\end{array}$ & Representation \\
\hline Equality & 1.0000 & 18 & .0000 & .0000 & \multirow[t]{2}{*}{.422} & \multirow[t]{2}{*}{ EQUAL } \\
\hline $\begin{array}{l}\text { Hispanic department } \\
\text { representation }\end{array}$ & 1.1294 & 18 & 6670 & .1572 & & \\
\hline & & & & & & \\
\hline Equality & 1.0000 & 18 & .0000 & .0000 & \multirow[t]{2}{*}{.013} & \multirow[t]{2}{*}{ UNDER } \\
\hline $\begin{array}{l}\text { Hispanic SU internal } \\
\text { representation }\end{array}$ & .7044 & 18 & 4496 & .1060 & & \\
\hline Equality & 1.0000 & 18 & .0000 & .0000 & \multirow{2}{*}{.733} & \multirow{2}{*}{ EQUAL } \\
\hline $\begin{array}{l}\text { Hispanic SU } \\
\text { representation }\end{array}$ & .9489 & 18 & 6243 & .1472 & & \\
\hline
\end{tabular}

A series of t-tests were conducted to determine if the difference between black, white, and Hispanic representation within the police departments and police specialty units was significant, utilizing the calculation of less than $(.05)$ as the 
indicator of equality. The results are displayed in tables 12,13 , and 14 .

TABLE 15

\begin{tabular}{|c|c|c|c|}
\hline & $\begin{array}{r}\text { t-test for } \\
\text { Equality of } \\
\text { Means } \\
\end{array}$ & & \\
\hline & & d & $\begin{array}{r}\text { Sig. (2- } \\
\text { tailed) }\end{array}$ \\
\hline $\begin{array}{l}\text { Pecentage of Blacks } \\
\text { in Department }\end{array}$ & 2.679 & 16 & .016 \\
\hline $\begin{array}{l}\text { Pecentage of Blacks } \\
\text { in Specialty Units }\end{array}$ & 3.228 & 16 & .005 \\
\hline
\end{tabular}

Independent Samples Test

TABLE 16

\begin{tabular}{|l|r|r|r|r|r|}
\hline Coefficients & $\begin{array}{r}\text { Unstandardized } \\
\text { Coefficients }\end{array}$ & $\begin{array}{r}\text { Standardized } \\
\text { Coefficients }\end{array}$ & Sig. \\
\hline & $\begin{array}{r}\text { Std. } \\
\text { Error }\end{array}$ & Beta & \\
\hline Constant) & -11.566 & 7.970 & & -1.451 .167 \\
\hline $\begin{array}{l}\text { Percentage of Population that is } \\
\text { Black }\end{array}$ & .990 & .096 & 1.009 & 10.265 & .000 \\
\hline Black Chief & 3.233 & 3.652 & .087 & .885 .390 \\
\hline
\end{tabular}

Note: a Dependent Variable: \% of Blacks in the Department

TABLE 17

\begin{tabular}{|l|r|r|r|r|r|}
\hline Coefficients & $\begin{array}{r}\text { Unstandardized } \\
\text { Coefficients }\end{array}$ & & $\begin{array}{r}\text { Standardize } \\
\text { d } \\
\text { Coefficients }\end{array}$ & Sig. \\
\hline & B & Std. Error & Beta & & \\
\hline (Constant) & 2.185 & 8.934 & & .245 & .810 \\
$\begin{array}{l}\text { Percentage of } \\
\text { Population that is } \\
\text { Black }\end{array}$ & .783 & .108 & .891 & 7.242 & .000 \\
\hline \begin{tabular}{l} 
Black Chief \\
\hline
\end{tabular} & -1.996 & 4.094 & -.060 & -.488 & .633 \\
\hline
\end{tabular}

Note: a Dependent Variable: \% of Blacks in Specialty Units 
Utilizing data related to black police chiefs and the percentage of blacks within the local population, I was unable to determine which had the greater influence on the number of black police officers represented in police departments and specialty units. In order to determine which had the greatest influence on black representation within police departments and police specialty units, a historical analysis and intensive interviews must be conducted.

Influence of the Race of the Chief:

Question 1: Do Black Chiefs influence the PERCENTAGE of blacks employed in department or specialty units?

- Answer: Yes. Departments with Black Chiefs were significantly more

- likely to have more blacks in the department and in the specialty units.

- Yet, how does percentage of the city population that is Black influence

- the percentage of blacks employed in the department or specialty units.

- Cities with a higher black population tend to have Black

- Chiefs and higher percentages of blacks in the department and

- specialty units.

- KEY CONCLUSION: A multiple regression analysis

- illustrated that percentage of Blacks in the city population

- provides a better explanation for why Blacks are more likely to

$\circ$ be in the department or in specialty units. 


\section{SUMMARY AND CONCLUSIONS}

The research and data obtained in this study provided mixed findings and failed to produce a sufficient amount of convincing evidence to prove or disprove that discrimination and nepotism exists within police specialty units or was a major factor for the under representation of black police officers in police departments and elite police specialty units. The research indicated that black police officer's representation within police departments and police specialty units was dependent upon three factors: 1 . black representation within the local population, 2. black representation within the police department, and 3. the race of the police chief.

The research indicated that minority representation within police specialty units and police departments, when compared to the local population appeared to be the lowest. However, minority representation did increase when calculated with representation within the department. Based on the findings of the research, it appears that the race of the police chief and the representation of Black Americans within the local population provided the strongest influence and had the greatest impact on the proportionate numbers of black police officers assigned to police specialty units and employed within the police departments..

An analysis of the data failed to provide a clear explanation for black police officer's over-representation and high index calculations within the police departments and police specialty units that participated in this study, and displayed a higher degree of equality. In order to determine if black police officer's 
representation within police departments and police specialty units is the result of the increased numbers of blacks within the local population, or the result of having a black police chief in charge of the organization, a historical analysis of the police department's personnel data, combined with personal interviews of police officers and chiefs of police in addition to examining census data must be preformed.

The research indicated that black police officers have encountered discrimination and racism for decades, when confronted with the various components criminal justice system and while acting in the official capacity of police officers. However, the research failed to present a correlation between the history of the criminal justice system and the disproportionate number of black police officers assigned to police specialty units.

Based on the data and research of this study, it appears that discrimination and nepotism exists within the law enforcement community, and act as barriers for advancement within the police organization. However, unlike the years of the past, discrimination and nepotism are less tolerated, consequently there are many avenues available to obtain a multitude of resolutions.

The research suggests, that black police officers have the best opportunity of becoming members of elite police specialty units in police departments that have a black chief of police and in cities that have a high representation of blacks within the in the local population. 


\section{BIBLIOGRAPHY}

Adversity. Net. "Illinois State Police Guilty of Reverse Discrimination" April 7th (1998).

Adversity. Net. "Black Female Sheriff Hires Her Own" Aug 17th (1997).

Alex, Nicholas. (1969) Black In Blue. New York: Meredith Publishing

Ali, Karen. (1997)."Black Police Officers Protest Hiring". The News-Times 14th

June sec 1 .

Ali, Karen (1997)."Men Testify About Police Job Denials In Discrimination case".

The News-Times 25th Sept sec1.

American Police Beat. " Bedlam Breaks Out In Lewisville After Popular Chief Is

Fired By Mayor" April (2000).

American Police Beat. "Minority Cops Fight To Keep Affirmation Action

Policies”. July (2000)

Billings, Andrew. (1968). Black Families In White America. Englewood Cliffs,

N.J: Prentice-Hall Publishing.

Cashmore, E. (1991). Out Of Order: Policing Black People. Routlege, London And New York.

Chambers, Bradford. (1968). Chronicles of Black Protest. New York: The New American Library Publishing.

Charles, Nick and Coleman, Chrisena. “ Badge Of Racism”. Emerge Sept (1995). 
Childs, Wesner."NAACP Report Outlines Allegations Of Discrimination By Police". Dec 20th (1996).

Clark, Kenneth. (1965). Dark Getto: Dilemmas Of Social Power: New York:

Harper and Row Publishing. Conley, John B. Historical Perspective And Criminal Justice.

Journal Of Criminal Justice Education: vol4. no.2. Fall (1993).

Dunlaney, Marvin W. (1996). Black Police In America. Indianapolis: Indiana University Press Publishing.

Finch, Tom. "192 Minority Police Officers File Suit In Chicago Alleging Bias in Sergeants Examination". Jet Oct (1994).

Fuller, Charlie (1998). The Art Of Undercover. Youngsville, NC: Law

Enforcement Associates Inc. Publishing.

Johnson, Ben. "Fighting Culture Misinformation About African-Americans".

(1993). Los Angeles Times. sec.1

Markowitz, Michael W. and Jones-Brown Delores D. (2000). The System In Black and White. Westport CN: Praeger Publishers.

Moss, Gary."City's Effort To Rescind Hiring Order Continues:" Fayetteville

Observer-Times. Feb. (1997).

Presidents Commission.(1967). The Challenge of Crime In A Free Society.

Washington, DC: United States Gov. Printing . 
Quarles, Benjamin.(1964). The Negro In The Making Of America. New York:Collier Publishing.

Reuters Limited. (1999). "Judge Refuses to Dismiss Race Suit Against NYC". $\sec 1$.

Rumler, John. "Minorities and The Law : Police Academy Breeds Racism". The Rap-sheet. Jan (1997). sec.15.

U.S. Bureau of Census. (1991). Statistical Abstracts of the United States.

Washington: U.S. Government Printing Office.

U.S. Bureau of Justice Statistics Sourcebook (1998).. Washington: U.S.

Government Printing Office.

U.S. Department of Justice. Bureau of Justice Statistics (2000). Washington: U.S. Government Printing Office.

U.S. Department of Justice . FBI Statistics (1992) Washington: U.S. Government Printing Office.

West, Cornel (1993) Race Matters. Boston, Mass: Beacon Publishing. 